\title{
Evaluation of the Effects of Precipitation on Ground-Water Levels from Wells in Selected Alluvial Aquifers in Utah and Arizona, 1936-2005
}


Scientific Investigations Report 2008-5242 



\section{Evaluation of the Effects of Precipitation on Ground-Water Levels from Wells in Selected Alluvial Aquifers in Utah and Arizona, 1936-2005}

By Philip M. Gardner and Victor M. Heilweil

Scientific Investigations Report 2008-5242 


\title{
U.S. Department of the Interior \\ KEN SALAZAR, Secretary
}

\author{
U.S. Geological Survey \\ Suzette M. Kimball, Acting Director
}

U.S. Geological Survey, Reston, Virginia: 2009

For product and ordering information:

World Wide Web: http://www.usgs.gov/pubprod

Telephone: 1-888-ASK-USGS

For more information on the USGS--the Federal source for science about the Earth, its natural and living resources, natural hazards, and the environment:

World Wide Web: http://www.usgs.gov

Telephone: 1-888-ASK-USGS

Any use of trade, product, or firm names is for descriptive purposes only and does not imply endorsement by the U.S. Government.

Although this report is in the public domain, permission must be secured from the individual copyright owners to reproduce any copyrighted materials contained within this report.

Suggested citation:

Gardner, P.M., and Heilweil, V.M., 2009, Evaluation of the effects of precipitation on ground-water levels from wells in selected alluvial aquifers in Utah and Arizona, 1936-2005: U.S. Geological Survey Scientific Investigations Report 2008-5242, 28 p. Available at http:// pubs.er.usgs.gov/sir/2008/5242. 


\section{Contents}

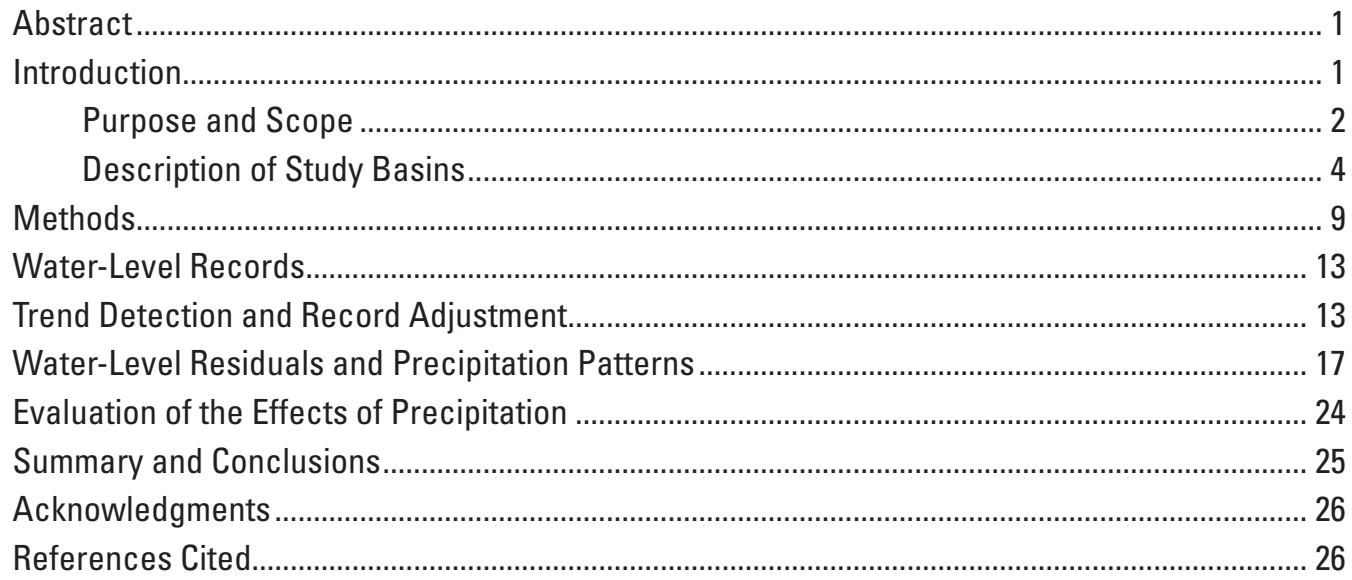

\section{Figures}

1. Map showing location of basins in Utah and Arizona with ground-water level records examined in this study

2. Graph showing average monthly precipitation for 1971-2000 from mountain precipitation stations near central Sevier and Milford basins in southwestern Utah and Aravaipa Canyon, Douglas, and Willcox basins in southeastern Arizona

3. Graph showing total annual precipitation for 1950-2003 and ground-water withdrawal (normalized by the area of the alluvial basin) for 1930-2003 from the central Sevier and Milford basins in southwestern Utah.

4. Graph showing total annual precipitation for 1930-2004 and ground-water withdrawal (normalized by the area of the alluvial basin) for 1930-2000 from Aravaipa Canyon, Douglas, and Willcox basins in southeastern Arizona

5. Map showing location of selected wells and precipitation stations in the central Sevier and Milford basins in southwestern Utah.

6. Map showing location of selected wells and precipitation stations in Aravaipa Canyon, Douglas, and Willcox basins in southeastern Arizona

7. Graphs showing spline-interpolated water-level records from central Sevier and Milford basins in Utah and Aravaipa Canyon, Douglas, and Willcox basins in southeastern Arizona, 1936-2005

8. Graphs showing water-level residuals for wells and moving averages of annual precipitation from weather stations in the central Sevier and Milford basins in Utah and Aravaipa Canyon, Douglas, and Willcox basins in southeastern Arizona, 1936-2005 


\section{Tables}

1. Wells used in analysis, level of development (pumping) that has occurred in each basin, information about the quality of the water-level record for each well, and aquifer condition and hydrologic setting for wells in central Sevier and Milford basins in Utah and Aravaipa Canyon, Douglas, and Willcox basins in southeastern Arizona ..... 10

2. Results of Mann-Kendall trend test on water-level records for wells in central Sevier and Milford basins in Utah and Aravaipa Canyon, Douglas, and Willcox basins in southeastern Arizona

3. Correlation coefficients between water-level residual time series and moving averages of precipitation, number of years used to calculate moving average, and aquifer condition and hydrologic setting for wells in central Sevier and Milford basins in Utah and Aravaipa Canyon, Douglas, and Willcox basins in southeastern Arizona. 


\section{Conversion Factors and Datums}

\begin{tabular}{|c|c|c|}
\hline Multiply & By & To obtain \\
\hline \multicolumn{3}{|c|}{ Length } \\
\hline inch (in.) & 2.54 & centimeter $(\mathrm{cm})$ \\
\hline foot $(\mathrm{ft})$ & 0.3048 & meter $(\mathrm{m})$ \\
\hline mile (mi) & 1.609 & kilometer $(\mathrm{km})$ \\
\hline \multicolumn{3}{|c|}{ Area } \\
\hline acre & 0.004047 & square kilometer $\left(\mathrm{km}^{2}\right)$ \\
\hline square mile $\left(\mathrm{mi}^{2}\right)$ & 2.59 & square kilometer $\left(\mathrm{km}^{2}\right)$ \\
\hline \multicolumn{3}{|c|}{ Volume } \\
\hline acre-foot (acre-ft) & 1,233 & cubic meter $\left(\mathrm{m}^{3}\right)$ \\
\hline acre-foot per square mile (acre-ft/mi²) & 476.1 & $\begin{array}{l}\text { cubic meter per square kilometer } \\
\left(\mathrm{m}^{3} / \mathrm{km}^{2}\right)\end{array}$ \\
\hline \multicolumn{3}{|c|}{ Flow rate } \\
\hline cubic foot per second $\left(\mathrm{ft}^{3} / \mathrm{s}\right)$ & 0.02832 & cubic meter per second $\left(\mathrm{m}^{3} / \mathrm{s}\right)$ \\
\hline cubic foot per second $\left(\mathrm{ft}^{3} / \mathrm{s}\right)$ & 646,317 & million gallons per day (Mgal/d) \\
\hline cubic foot per second $\left(\mathrm{ft}^{3} / \mathrm{s}\right)$ & 448.8 & gallons per minute (gal/min) \\
\hline
\end{tabular}

Temperature in degrees Celsius $\left({ }^{\circ} \mathrm{C}\right)$ may be converted to degrees Fahrenheit $\left({ }^{\circ} \mathrm{F}\right)$ as follows:

$$
{ }^{\circ} \mathrm{F}=\left(1.8 \times^{\circ} \mathrm{C}\right)+32 \text {. }
$$

Temperature in degrees Fahrenheit $\left({ }^{\circ} \mathrm{F}\right)$ may be converted to degrees Celsius $\left({ }^{\circ} \mathrm{C}\right)$ as follows:

$$
{ }^{\circ} \mathrm{C}=\left({ }^{\circ} \mathrm{F}-32\right) / 1.8 \text {. }
$$

Horizontal coordinate information is referenced to the North American Datum of 1983 (NAD 83).

Vertical coordinate information is referenced to the North American Vertical Datum of 1988 (NAVD 88).

Altitude, as used in this report, refers to distance above the vertical datum. 


\title{
Evaluation of the Effects of Precipitation on Ground-Water Levels from Wells in Selected Alluvial Aquifers in Utah and Arizona, 1936-2005
}

\author{
By Philip M. Gardner and Victor M. Heilweil
}

\section{Abstract}

Increased withdrawals from alluvial aquifers of the southwestern United States during the last half-century have intensified the effects of drought on ground-water levels in valleys where withdrawal for irrigation is greatest. Furthermore, during wet periods, reduced withdrawals coupled with increased natural recharge cause rising ground-water levels. In order to manage water resources more effectively, analysis of groundwater levels under the influence of natural and anthropogenic stresses is useful.

This report evaluates the effects of precipitation patterns on ground-water levels in areas of Utah and Arizona that have experienced different amounts of ground-water withdrawal. This includes a comparison of water-level records from basins that are hydrogeologically and climatologically similar but have contrasting levels of ground-water development. Hydrologic data, including records of ground-water levels, basinwide annual ground-water withdrawals, and precipitation were examined from two basins in Utah (Milford and central Sevier) and three in Arizona (Aravaipa Canyon, Willcox, and Douglas). Most water-level records examined in this study from basins experiencing substantial ground-water development (Milford, Douglas, and Willcox) showed strong trends of declining water levels. Other water-level records, generally from the less-developed basins (central Sevier and Aravaipa Canyon) exhibited trends of increasing water levels. These trends are likely the result of accumulating infiltration of unconsumed irrigation water.

Water-level records that had significant trends were detrended by subtraction of a low-order polynomial in an attempt to eliminate the variation in the water-level records that resulted from ground-water withdrawal or the application of water for irrigation. After detrending, water-level residuals were correlated with 2- to 10-year moving averages of annual precipitation from representative stations for the individual basins. The water-level residual time series for each well was matched with the 2- to 10-year moving average of annual precipitation with which it was best correlated and the results were compared across basins and hydrologic settings.
Analysis of water-level residuals and moving averages of annual precipitation indicate that ground-water levels in the Utah basins respond more slowly to precipitation patterns than those from the Arizona basins. This is attributed to the dominant mechanism of recharge that most directly influences the respective valley aquifers. Substantial recharge in the Utah basins likely originates as infiltrating snowmelt in the mountain block far from the valley aquifer, whereas mountain-front recharge and streambed infiltration of runoff are the dominant recharge mechanisms operating in the Arizona basins. It was determined that the fraction of water-level variation caused by local precipitation patterns becomes more difficult to resolve with increasing effects of ground-water pumping, especially from incomplete records. As the demand for ground water increases in the southwestern United States, long-term records of ground-water levels have the potential to provide valuable information about the precipitation-driven variation in water levels, which has implications to water management related to water availability.

\section{Introduction}

Ground water is among the most important of the natural resources in the arid southwestern United States. It provides water for drinking, irrigation, and industry in addition to sustaining the flow in streams and rivers, and maintaining riparian and wetland ecosystems. The demand for ground water is rapidly increasing in the southwestern United States at the same time that climate change is predicted to affect sources of recharge to southwestern aquifers (Dettinger and Earman, 2007; Seager and others, 2007). Ground-water development during the past 50 years has diminished this resource by lowering water levels in many areas. From 1950 to 2000, total ground-water withdrawals for five southwestern states (Arizona, California, Nevada, New Mexico, and Utah) increased an average of 62 percent regionally, but as much as 324 percent in Nevada, 208 percent in Utah, and 147 percent in New Mexico (Konieczki and Heilman, 2004). Total withdrawals from all Basin and Range alluvial aquifers during the 
year 2000 were more than 6 million acre-ft $(5,620 \mathrm{Mgal} / \mathrm{d})$, which is about 7 percent of total ground-water withdrawals in the United States (Maupin and Barber, 2005). Withdrawals for irrigation accounted for more that 80 percent $(4,550 \mathrm{Mgal} / \mathrm{d})$ of this total while 18 percent $(1,010 \mathrm{Mgal} / \mathrm{d})$ was for public supply. The effects of increasing ground-water withdrawals are evident; they have been studied and are commonly considered in future scenarios of ground-water management. Less obvious are the effects of natural climatic variation on ground-water systems.

Ground-water systems are affected by climate on a variety of time scales. Venencio (2002) identified correlations of low-frequency variations between precipitation and ground-water levels in an unconfined aquifer in Argentina. Sufflita and Kern (2001) used the Palmer Hydrologic Drought Index to successfully reconstruct variations in discharge from springs in central Utah. Other recent reports (Hanson, Martin, and Koczot, 2002; Hanson, Newhouse, and Dettinger, 2004; and Hanson, Dettinger, and Newhouse, 2006) have identified variations in ground-water levels that are associated with multi-year to multi-decadal cyclic climatic phenomena such as the Pacific Decadal Oscillation, El Niño/Southern Oscillation, and the North American Monsoon. Despite this recognition, water-management decisions that have implications for natural systems as well as management and planning scenarios have traditionally been based on the long-term average behavior of aquifers. The demand for ground water as a primary source of water supply is increasing as surface-water supplies are appropriated and, as this happens, margins for error in waterresource decisions are becoming narrower. Furthermore, aquifer response to climate variability can lead to changes in ground-water quality and can affect contaminant transport (Alley, 2001). For these reasons, future analysis of groundwater systems will require more-detailed inclusion of climatedriven variation.

Drought is the most widely recognized climatic condition related to ground-water levels (Alley, 2001). The recent (1999-2004) drought is only one of many multi-year droughts that affected ground-water levels in the southwestern United States during the last century (U.S. Geological Survey, 1991). Tree-ring reconstructions of climate in the southwestern United States indicate that the last 200 years have been the wettest period in the past 2,200 years and that sustained droughts have occurred during this time that were drier and longer in duration than any in the $20^{\text {th }}$ century (Merideth, 2000). Human-induced climate change in the coming decades may further affect ground-water resources. Changes in groundwater recharge (both increases and decreases) are likely to result from changes in the annual and seasonal distribution of precipitation and temperature.

The analysis of long-term measurements of groundwater levels provides an opportunity to examine the effects of drought and precipitation on southwestern aquifers and to make inferences about the physical processes that control transient changes in aquifer storage. Natural recharge to southwestern aquifers is generally low. During droughts, natural recharge is reduced at the same time that ground-water resources are increasingly being used because of the lack of available surface water. This reduced recharge coupled with increased ground-water withdrawal has the effect of temporarily amplifying the decline of ground-water levels. The opposite is true during episodes of greater-than-average precipitation, when less ground-water pumping occurs. These anthropogenic influences make it difficult to determine the magnitude of human versus climatic effects on ground-water levels. For these reasons, ground-water levels from wells in undeveloped basins (those unaffected by anthropogenic stresses such as pumping and irrigation) would be useful information to have in order to evaluate the response of groundwater levels to precipitation patterns. Unfortunately long-term records from undeveloped basins are rare and evaluating the effects of drought and precipitation on ground-water levels must be done on records where anthropogenic influences are present.

In recognition of the need to study climatic influences on ground water, the U.S. Geological Survey (USGS) established a nationwide water-level monitoring network in 1998 of more than 100 wells in minimally disturbed aquifers (U.S. Geological Survey, 2008). In the future, records from these wells will provide a foundation for evaluating the effects of drought and climate change on ground-water systems. Currently, few longterm ground-water level records are available from undeveloped southwestern aquifers.

This study was designed to evaluate the effects of variations in precipitation on ground-water levels in alluvial aquifers from five basins in Utah and Arizona (fig. 1). A secondary objective was to make inferences about the basin and aquifer characteristics that control natural (climate driven) water-level variation and our ability to resolve this variation in areas where water-level change is dominantly controlled by anthropogenic influences (pumping and irrigation). In order to achieve these objectives, water-level records were examined from wells in a variety of hydrogeologic settings and from basins that have experienced different levels of ground-water withdrawal. The selected basins were intended to represent the climatic and hydrogeologic characteristics common to many basins in the southwestern United States. Water-level and precipitation data were compared across basins and hydrogeologic settings.

\section{Purpose and Scope}

This report documents a comparative analysis of the effects of local precipitation patterns on existing long-term water-level records from wells in various hydrogeologic settings in five basins in Utah and Arizona (fig. 1). The locations were chosen such that neighboring basins in each state are at similar altitudes and receive similar precipitation while experiencing notably different levels of ground-water development. The response of ground-water levels to precipitation patterns for records from 24 wells from these basins in Utah and Arizona is evaluated. 


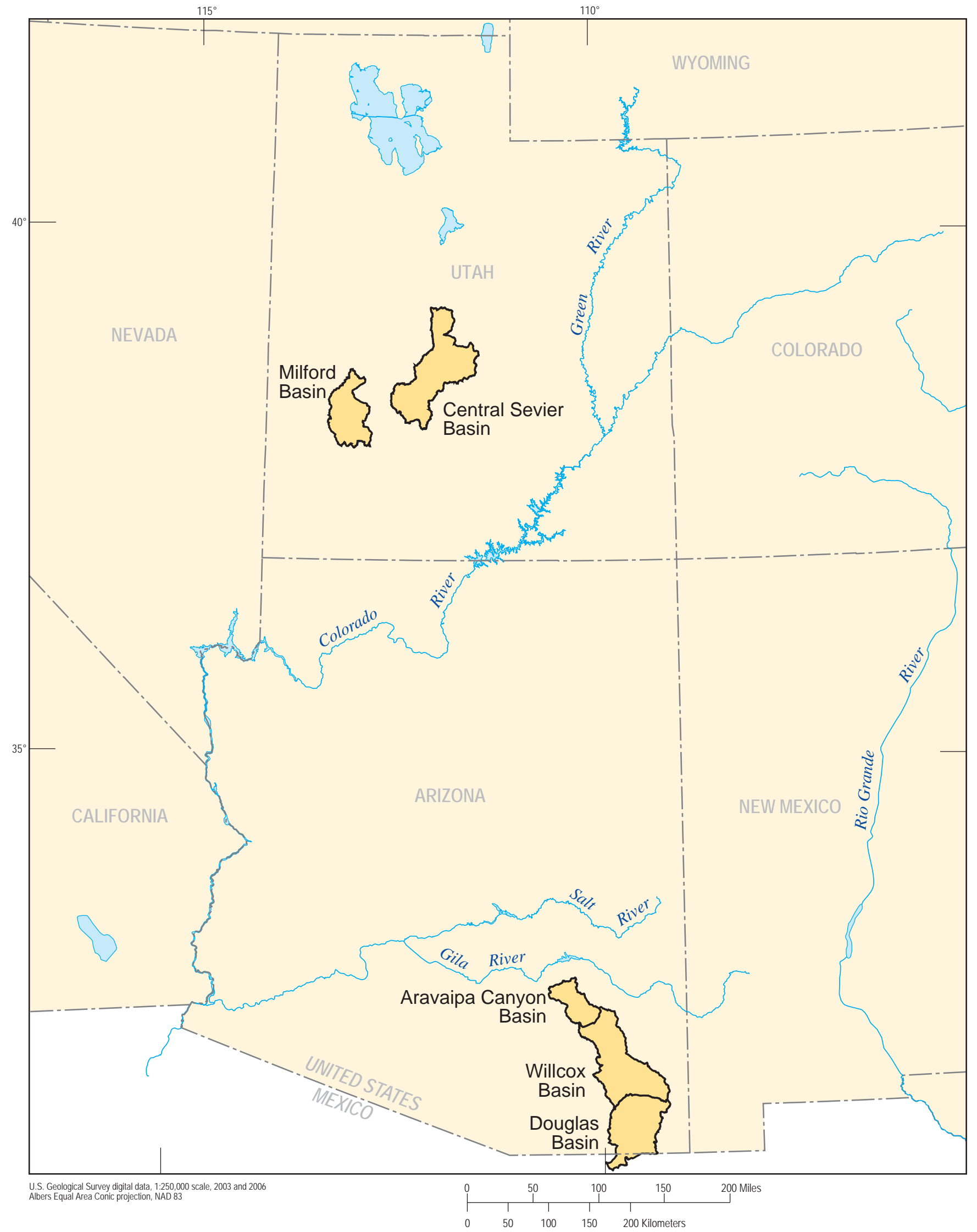

Figure 1. Location of basins in Utah and Arizona with ground-water level records examined in this study. 


\section{Description of Study Basins}

The basins discussed in this report are the central Sevier and Milford basins in southwestern Utah and the Aravaipa Canyon, Douglas, and Willcox basins in southeastern Arizona (fig. 1). All of these basins are located in the Basin and Range Physiographic Province (Fenneman, 1931) and contain thick deposits of unconsolidated sand and gravel of Tertiary and Quaternary age that were eroded from basin-bounding mountain ranges (Planert and Williams, 1995). These basins were selected because they are representative of hydrogeologic and climatologic conditions present in many Basin and Range areas in Utah and Arizona, as well as the spectrum of levels of ground-water development. While the Arizona basins receive more summer precipitation from monsoonal weather patterns, the Utah basins receive more high-elevation precipitation from winter storms. This is illustrated by average monthly precipitation from mountain precipitation stations located near the study basins in Utah and Arizona (fig. 2). Despite the difference in seasonal precipitation between the Utah and Arizona basins, neighboring basins in each state that experience vastly different levels of ground-water development receive similar precipitation to one another (figs. 3 and 4). In the following discussions, the term basin refers to the larger catchment or surface-water drainage that includes much of the mountainous area that surrounds a valley and the term valley refers only to the smaller, low-elevation alluvial portion of each basin. In order to more evenly compare the magnitude of the effects of pumping on ground-water levels from the basins, annual withdrawals are normalized by the area of the valley within each basin so that annual ground-water withdrawal is reported in acre-feet per square mile (figs. 3 and 4).

The central Sevier basin is a northeast-trending basin of about 1,900 $\mathrm{mi}^{2}$ located along the transition between the Basin and Range and Colorado Plateau Physiographic Provinces (Fenneman, 1931) in central Utah. The 350- in $^{2}$ alluvial valley in the center of the basin is surrounded by the Sevier and Wasatch Plateaus to the east and the Tushar and Valley Mountains and the Pahvant Range to the west (fig. 5). Altitudes range from about $5,100 \mathrm{ft}$ on the valley floor to more than $12,000 \mathrm{ft}$ in the Tushar Mountains. Average annual precipitation is about 8 in. on the valley floor (fig. 3) and about 30 in. in the surrounding mountains (Lambert and others, 1995).

The principal source of ground water in the central Sevier basin is unconsolidated alluvium where ground water is under unconfined and confined conditions. Unconfined conditions exist primarily in the southern part and along the west margin of the valley. The unconfined zones are composed of coarsegrained sand and gravel deposits that correlate laterally with the water-bearing units that make up the confined zones in the northern half of the basin. Recharge to the alluvial aquifer occurs by infiltration of precipitation, seepage from canals, streams, and irrigated fields, and by inflow from consolidated rocks. The primary source of recharge is seepage from an extensive irrigation system with the majority likely occurring where water is applied to irrigated fields (Lambert and others, 1995). Ground water makes up only a small percentage of the

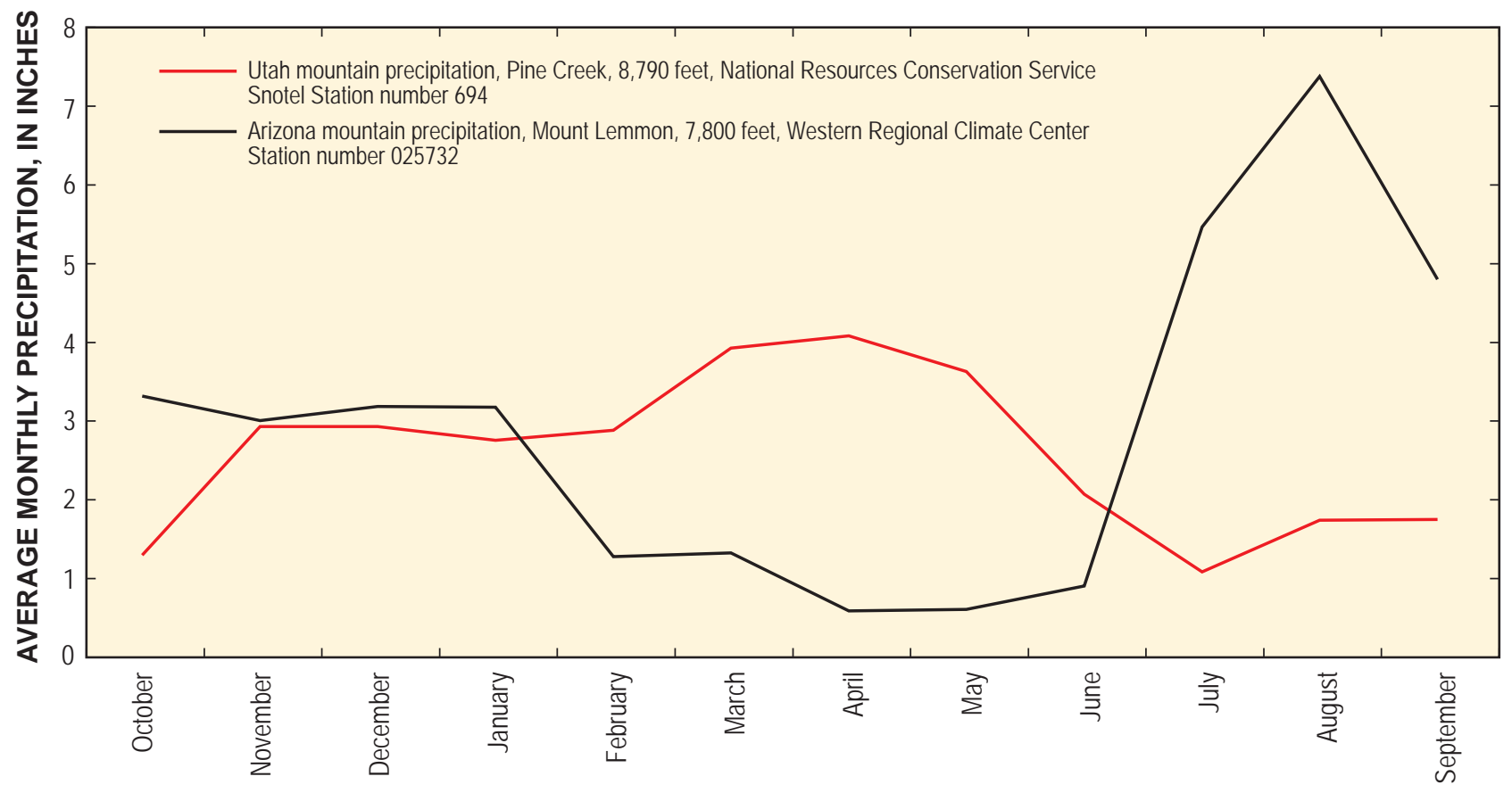

Figure 2. Average monthly precipitation for 1971-2000 from mountain precipitation stations near central Sevier and Milford basins in southwestern Utah and Aravaipa Canyon, Douglas, and Willcox basins in southeastern Arizona. 

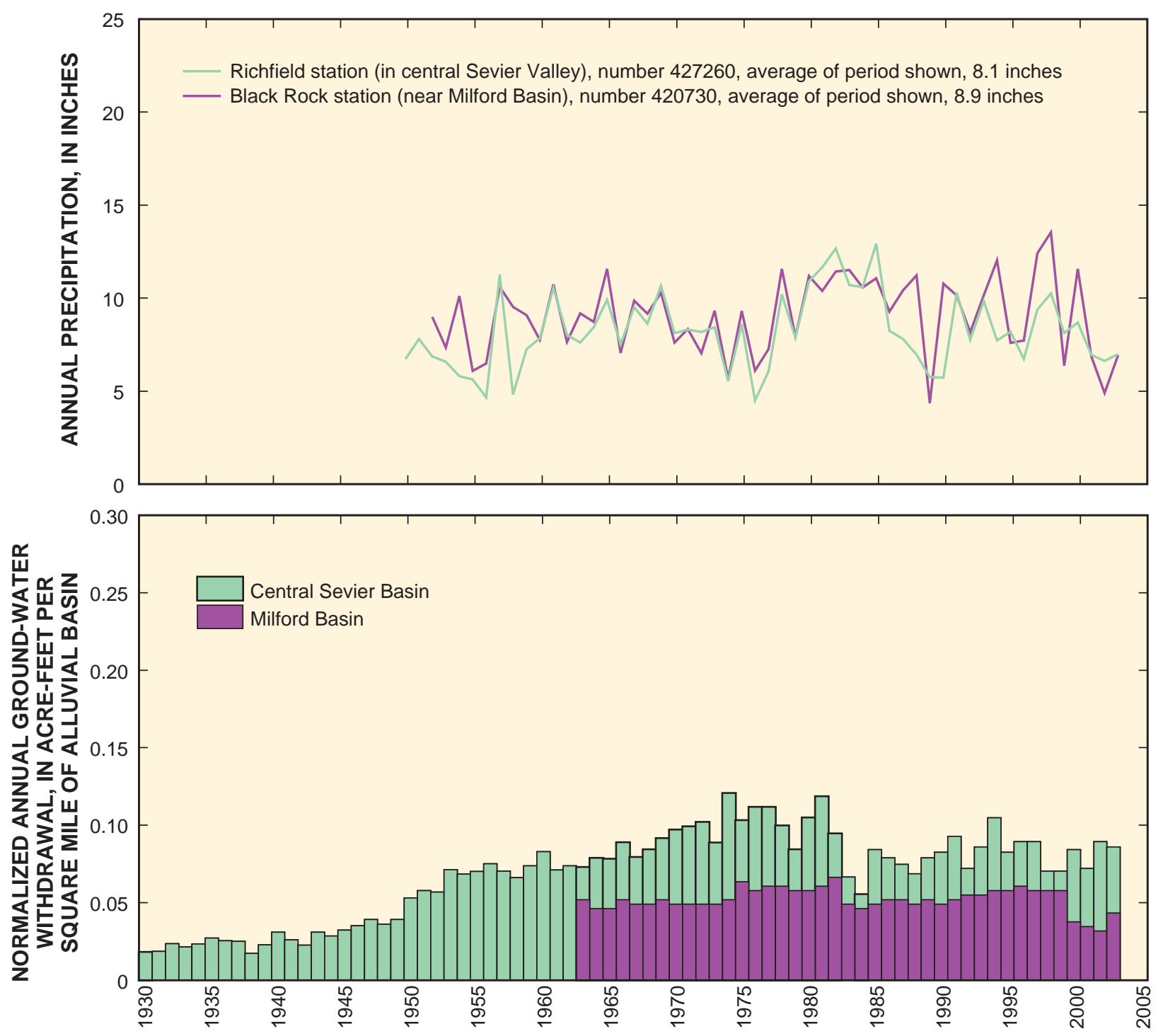

Figure 3. Total annual precipitation for 1950-2003 and ground-water withdrawal (normalized by the area of the alluvial basin) for 1930-2003 from the central Sevier and Milford basins in southwestern Utah.

water used for irrigation. The 1963 to 2003 average annual ground-water withdrawal was 18,000 acre-ft. Nearly 80 percent of all ground-water discharge is by seepage to the Sevier River, by evapotranspiration, and from springs in the northern half of the valley. Smaller amounts occur from wells, by seepage to drains, and by subsurface flow out of the basin.

Milford basin is located about $20 \mathrm{mi}$ southwest of central Sevier basin in southwestern Utah (fig. 5). The entire basin is about $920 \mathrm{mi}^{2}$ and encompasses an alluvial valley of around $580 \mathrm{mi}^{2}$. The basin is bounded by the Cricket Mountains on the north, the Black Mountains on the south, the Mineral Mountains on the east, and the San Francisco Mountains on the west. Most of the valley is at altitudes of about 4,850 to $5,500 \mathrm{ft}$ and the bulk of the surrounding mountainous area is between 5,500 and 9,000 ft. Low-elevation topographic highs generally delineate the basin divide where mountains are not present. Average annual precipitation is about 9 in. on the val- ley floor (fig. 3) and as much as about 25 in. in the surrounding mountains (Mower and Cordova, 1974).

The primary ground-water reservoir in Milford basin is in unconsolidated alluvium that is generally unconfined along the margins of the basin but becomes confined in the center of the southern one-half of the basin where the main area of agricultural development is located (Mason, 1998). About 80 percent of all recharge to the ground-water system is estimated to come from three sources: subsurface inflow from the Mineral Mountains, seepage of water applied to irrigated lands, and seepage of water diverted through canals from the Beaver River. The general direction of ground-water movement is from south to north with a strong east-to-west component, suggesting that most recharge occurs along the mountain front of the Mineral Mountains and near Minersville where the Beaver River enters the valley through a gap between the Mineral and Black Mountains (Mason, 1998). The largest component of 

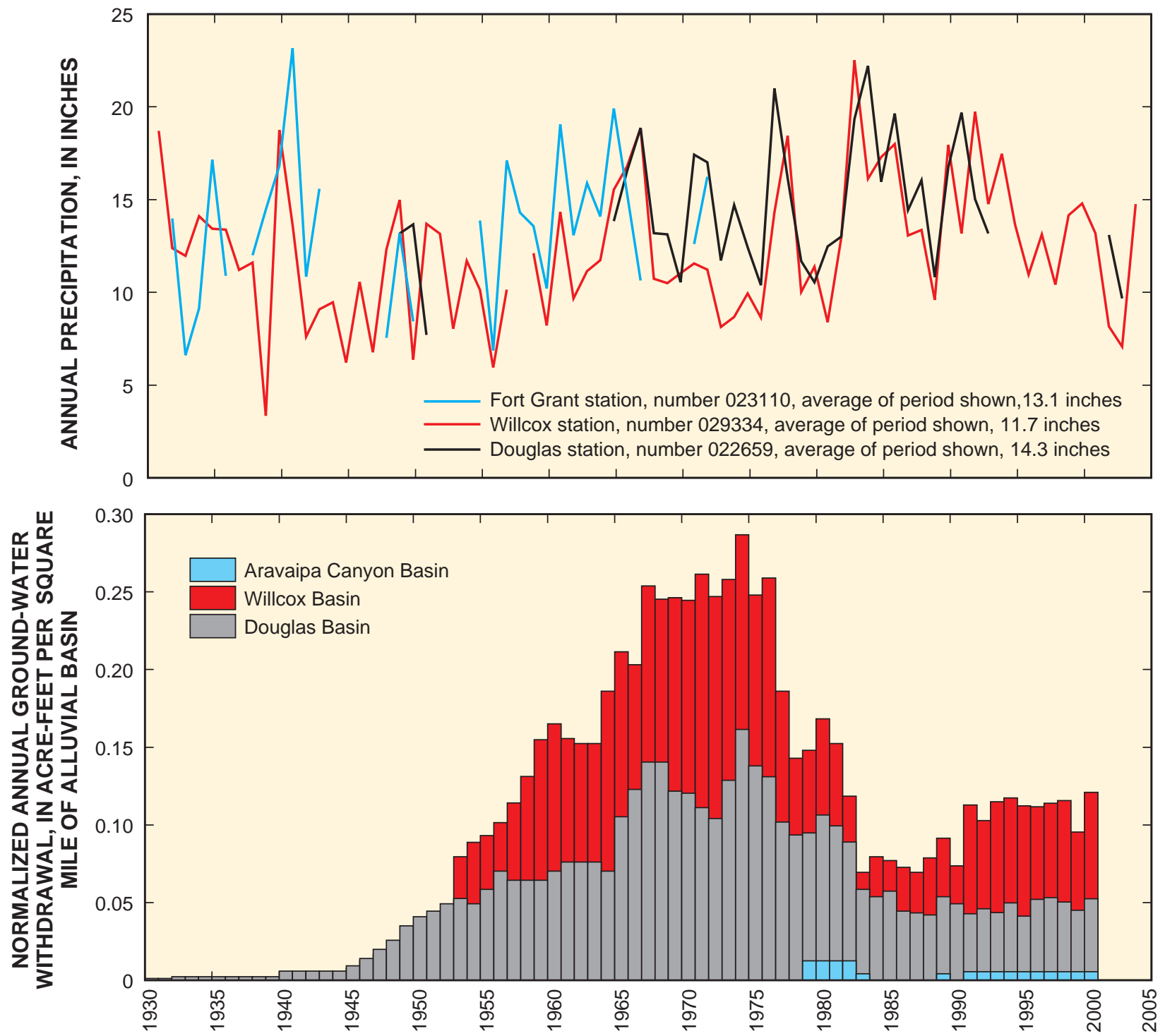

Figure 4. Total annual precipitation for 1930-2004 and ground-water withdrawal (normalized by the area of the alluvial basin) for 19302000 from Aravaipa Canyon, Douglas, and Willcox basins in southeastern Arizona.

ground-water discharge from the Milford basin is withdrawal for irrigation. From 1930 to 1949, annual ground-water withdrawal averaged about 16,000 acre-ft. From 1950 to 2000, the annual average was 48,000 acre-ft with a maximum of 70,000 acre-ft in 1974 (Burden and others, 2004). Ground-water levels began to decline after 1950 in association with the increase in ground-water withdrawals.

Aravaipa Canyon basin is a northwest-trending basin that occupies about $550 \mathrm{mi}^{2}$ in southeastern Arizona (figs. 1 and $6)$. The surface-water divide that defines the basin follows the crest of the Galiuro Mountains to the southwest and the Santa Teresa and Pinaleno Mountains to the northeast. A topographic high to the southeast marks the surface-water divide between Aravaipa Canyon basin and Willcox basin to the south. The alluvial extent of the basin is a $240-\mathrm{mi}^{2}$ valley that ranges from 4,300 to $3,100 \mathrm{ft}$ in altitude and is surrounded by mountains with altitudes of as much as 7,500 ft. Average annual precipi- tation for all three Arizona basins ranges from about 12 to 14 in. on the valley floor (fig. 4) and is about 25 in. in much of the surrounding mountains (Spatial Climate Analysis Service, 2004).

There are two aquifers in Aravaipa Canyon basin: an unconfined aquifer in streambed alluvium and a confined alluvial aquifer (Neuman and Adar, 1983). The upper, unconfined aquifer is the source of most water in the basin and is where the wells used in this study are located. Water levels in this aquifer range from about 10 to $100 \mathrm{ft}$ below land surface and indicate that ground-water movement is from the surrounding mountains to the valley floor and then through the valley toward the northwest (Arizona Department of Water Resources, 2005). Mountain-front recharge and streambed infiltration of runoff are the major sources of recharge to the unconfined aquifer. Water is discharge from the aquifer by ground-water pumpage and as base flow to Aravaipa Creek. 


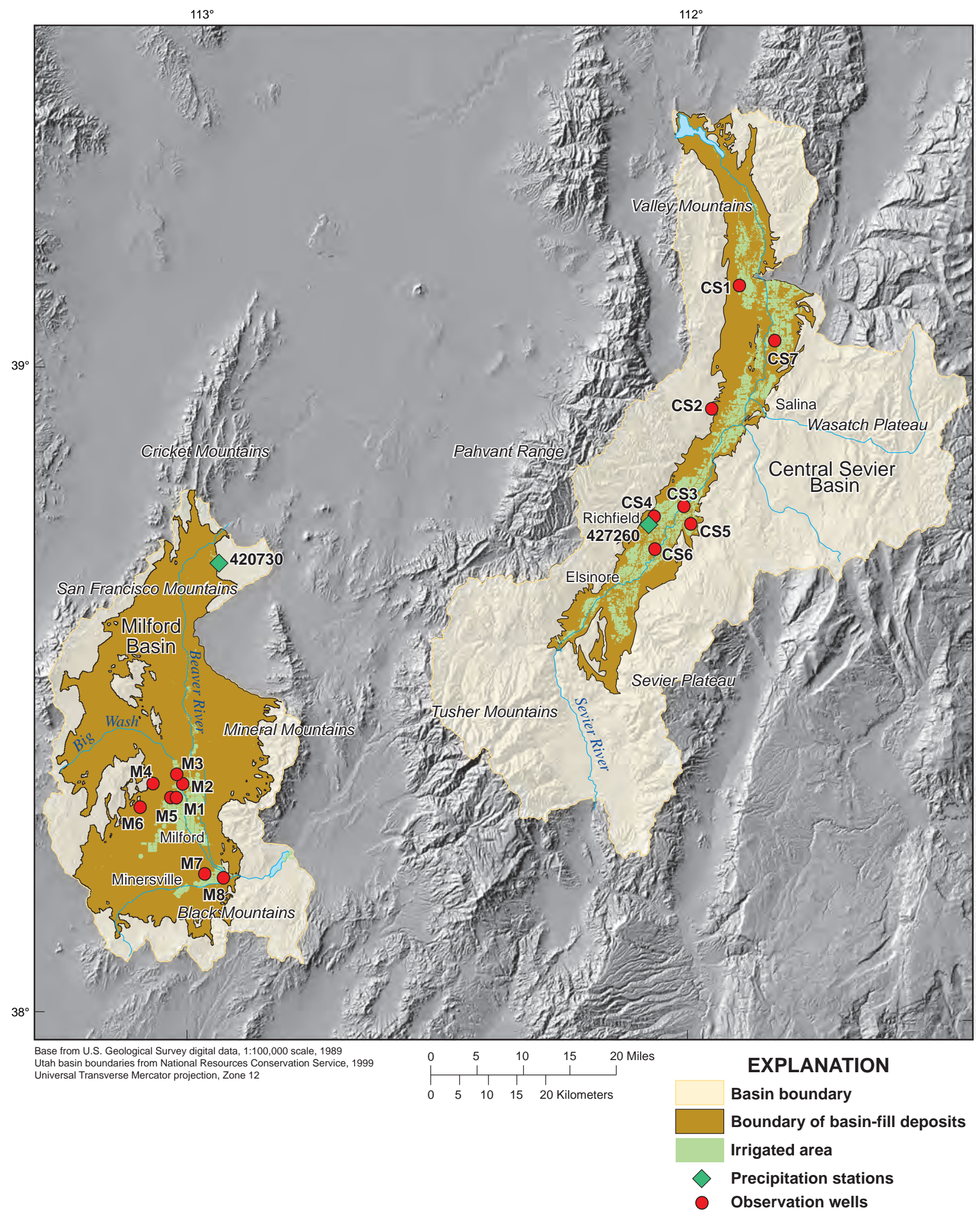

Figure 5. Location of selected wells and precipitation stations in the central Sevier and Milford basins in southwestern Utah. 


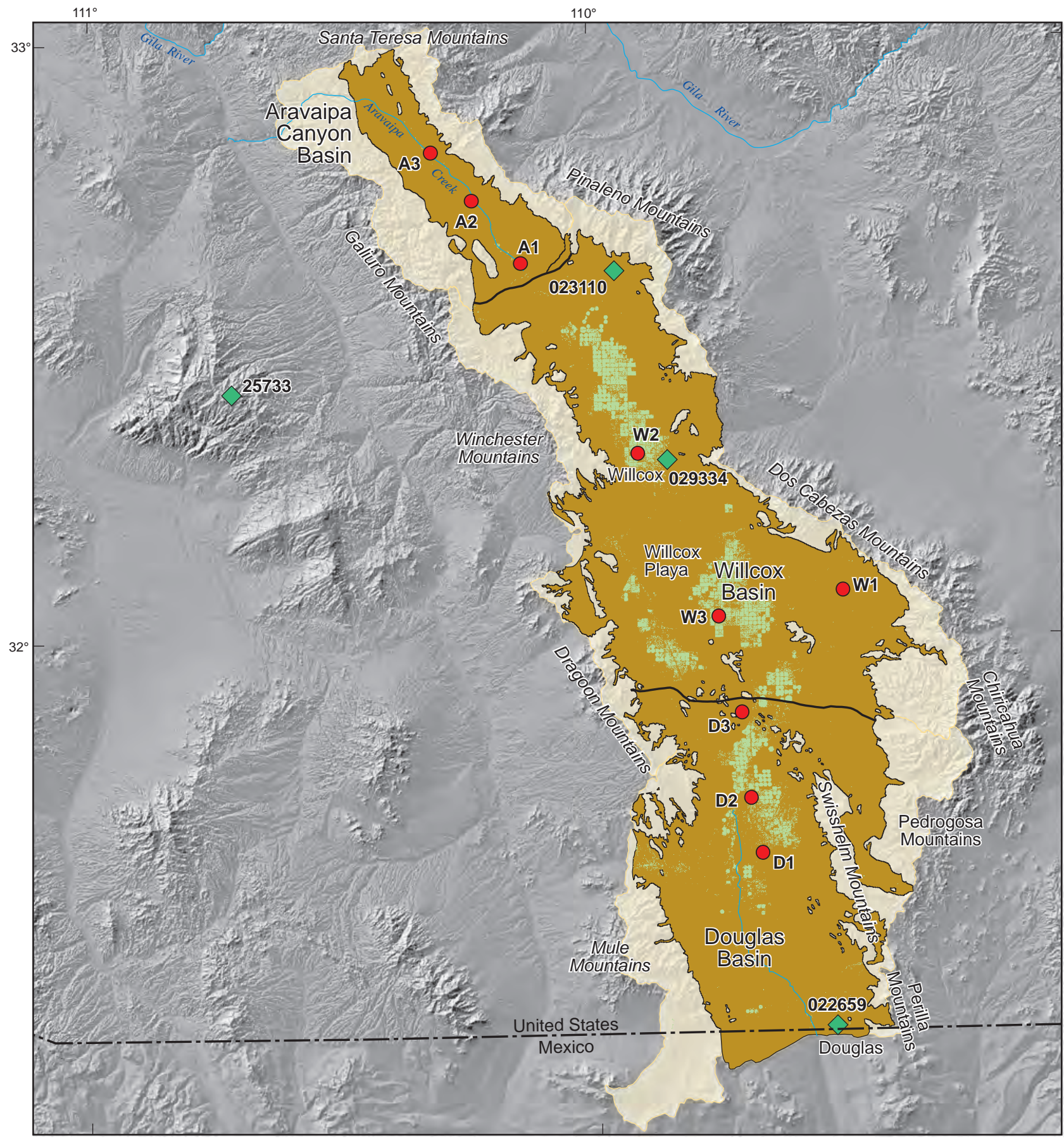

Base from U.S. Geological Survey digital data, 1:100,000 scale, 1989 Arizona basin boundaries from Anning and Konieczki,
Universal Transverse Mercator projection, Zone 12

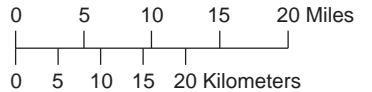

\section{EXPLANATION}

Basin boundary

Boundary of basin-fill deposits Irrigated area

$\diamond$ Precipitation stations

Observation wells

Figure 6. Location of selected wells and precipitation stations in Aravaipa Canyon, Douglas, and Willcox basins in southeastern Arizona. 
Most ground water is used for irrigating small fields located near Aravaipa Creek in the center of the valley. Since 1957, annual ground-water withdrawals have remained fairly steady at about 3,100 acre-ft with about 2,400 acre-ft coming from the unconfined aquifer (Arizona Department of Water Resources, 2005).

Willcox basin occupies about $1,700 \mathrm{mi}^{2}$ south of Aravaipa Canyon basin in southeast Arizona (figs. 1 and 6). It is a closed basin surrounded by topographically higher areas and is considered to be a solitary watershed. All surface drainage is internal and flows toward the Willcox Playa in the central part of the basin (Arizona Department of Water Resources, 2005). The alluvial extent of the basin is about 1,200 $\mathrm{mi}^{2}$ and is bounded by the Pinaleno Mountains to the northeast, the Dos Cabezas and Chiricahua Mountains to the east, and the Dragoon and Winchester Mountains to the west. Altitudes range from 4,130 $\mathrm{ft}$ at Willcox Playa to more than $10,700 \mathrm{ft}$ at Mount Graham.

Alluvial deposits are the primary source of ground water used mostly for irrigation in Willcox basin. Alluvium in Willcox basin consists of a mixture of stream and lake deposits. Where wells withdraw water from coarse-grained stream deposits, they yield more than 2,000 gal/min. Lake deposits consisting of mostly clay are interbedded with stream deposits and act as a confining layer that creates localized artesian conditions near Willcox Playa (Arizona Department of Water Resources, 2005). Mountain-front recharge and streambed infiltration of runoff are the major sources of recharge to the aquifer in Willcox basin. Nearly all ground-water discharge from Willcox basin is by pumpage. Ground-water withdrawals averaging about 300,000 acre-ft/yr during 1967-75 resulted in substantial ground-water declines in developed parts of the basin. Prior to extensive ground-water withdrawals, the direction of ground-water flow in the basin was generally from the basin perimeter toward Willcox Playa near the basin center. By 1975, large cones of depression had developed and the direction of ground-water flow was toward the pumping centers in the agricultural areas along the valley floor (Mann and others, 1978). Ground-water withdrawals peaked in the early to mid 1970s and have declined since then as farmland has been taken out of production (Arizona Department of Water Resources, 2005).

The Douglas basin covers about 1,200 $\mathrm{mi}^{2}$ between the Willcox basin to the north and the State of Sonora, Mexico to the south (figs. 1 and 6). The basin is bounded by the Swisshelm, Pedrogosa, and Perilla Mountains on the east and the Mule and Dragoon Mountains on the west. The basin is bounded on the north by an area of unnamed hills and on the south by the International Boundary with Mexico. Between the mountains that border the basin on the east and west is a broad, southward-sloping alluvial valley of about $860 \mathrm{mi}^{2}$. Altitudes range from about 3,900 ft in the valley bottom along the International Boundary to 7,200 ft in the Swisshelm Mountains. All surface-water channels within the basin are ephemeral and flow only in response to local rainfall (Arizona Department of Water Resources, 2005).
Douglas basin has no reliable surface-water supplies and is entirely dependant on ground water (Arizona Department of Water Resources, 2005). Most ground water in the Douglas basin comes from sand and gravel lenses in the alluvial aquifer and is used to supply large-capacity irrigation wells. The presence of a regional water table indicates that the sand and gravel lenses are generally interconnected and that the aquifer is mostly unconfined (Coates and others, 1955). Confined conditions do exist in the southern part of the basin at depths of more $500 \mathrm{ft}$; however, no wells used in this study are screened in the confined aquifer. Mountain-front recharge derived from mountain precipitation is the primary source of recharge to the alluvial aquifer and has been estimated to average 20,000 acre$\mathrm{ft} / \mathrm{yr}$ (Coates and others, 1955). Rainfall on the valley floor provides almost no recharge to the alluvial aquifer because of high evaporation rates and the presence of low-permeability caliche layers. Most ground-water discharge from the basin is by pumpage with minor amounts occurring as evapotranspiration, base flow, and underflow. Prior to ground-water development for irrigation in the late 1940s, ground water moved from mountain-front recharge areas toward the center of the basin and then south toward Mexico. Ground-water pumpage for irrigation has since created several cones of depression that have reversed the direction of ground-water flow in the southern part of the basin from south to north (Mann and English, 1980). From 1950 to 1990, annual ground-water withdrawals from Douglas basin averaged 72,000 acre-ft with a maximum of 138,000 acre-ft in 1974 .

\section{Methods}

Time-series data of ground-water levels and precipitation were used to evaluate the effects of precipitation patterns on ground-water levels. The methods used in this study employ readily available data from national or regional databases and are appropriate for making broad but meaningful (firstorder) interpretations without performing detailed hydrologic studies on particular basins. Water-level and precipitation data are referred to by local identifiers that allow reference back to their respective databases. Precipitation stations were referenced by their name and six-digit station number from the Western Regional Climate Center online database (http:// www.wrcc.dri.edu) in figures 3 through 6. Wells were identified by their public land survey system (PLSS) coordinates, which are composed of the township, range, section, quarterquarter-quarter section, and a sequence number within that quarter section, from the USGS National Water Information System (NWIS) database (http://waterdata.usgs.gov/nwis/gw). The PLSS well numbers are provided in table 1 and crossreferenced to a basin identifier (for example, CS1 through CS7 for the seven wells in the central Sevier basin) used elsewhere in this report. 
Prior to analysis, the following steps were performed:

1. annual ground-water withdrawals for each basin were normalized by the areal extent of the corresponding alluvial valley,

2. water-level and precipitation data were selected based on the location of the well or precipitation station and the length and completeness of their record,

3. selected wells were categorized according to their aquifer condition and hydrologic setting within the basin,
4. water-level data were pre-processed to yield a regular time-series of annual water levels to allow for quantitative comparisons (correlation) to simple moving averages of annual precipitation,

5. processed water-level data were analyzed for long-term trends likely caused by anthropogenic stresses (for example, ground-water withdrawals or application of surface-water for irrigation), and

Table 1. Wells used in analysis, level of development (pumping) that has occurred in each basin, information about the quality of the water-level record for each well, and aquifer condition and hydrologic setting for wells in central Sevier and Milford basins in Utah and Aravaipa Canyon, Douglas, and Willcox basins in southeastern Arizona.

[Level of ground-water development for each basin is categorized by peak normalized annual ground-water withdrawals: Low $=0$ to 0.1 acre-foot per square mile, Moderate $=0.1$ to 0.15 acre-foot per square mile, High $=$ more than 0.15 acre-foot per square mile. Percent of record that is complete is the number of years within the period of record for which there is at least one measurement divided by the number of years in the period of record. Number of measurements examined is the number of non-pumping season water levels. Aquifer condition - hydrologic setting: $\mathrm{C}$ - confined, $\mathrm{U}-\mathrm{unconfined,} \mathrm{MB}-\mathrm{middle}$ basin, $\mathrm{MF}-$ mountain front, $\mathrm{PC}$ - pumping center; for example, $\mathrm{C}$ - MB is confined - middle basin. —, no data]

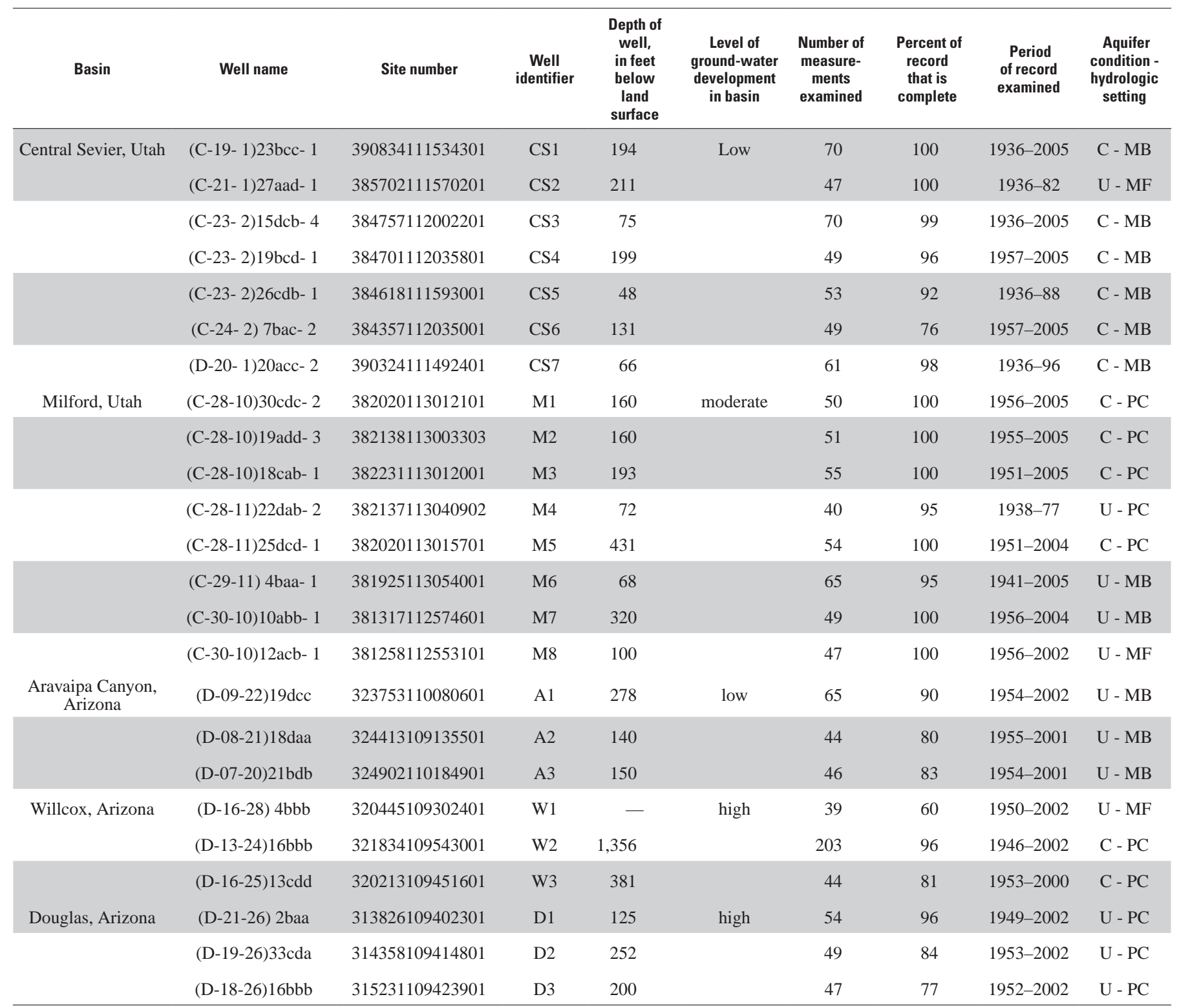


6. water-level time series that exhibited significant trends were detrended by subtraction of a low-order regressionfitted polynomial.

Records of annual ground-water withdrawals are generally complete and continuous for the period of time over which they are available in each basin. The annual sum of ground-water withdrawals for each basin was normalized by the areal extent of the corresponding alluvial valley (figs. 3 and 4). This provided a measure of the level of ground-water development that each basin has experienced that was comparable across basins. Each basin was also categorized according to its peak (normalized) annual withdrawal as follows; Low = 0 to 0.1 acre-ft $/ \mathrm{mi}^{2}$, Moderate $=0.1$ to 0.15 acre- $\mathrm{ft} / \mathrm{mi}^{2}$; High $=$ more than $0.15 \mathrm{acre}-\mathrm{ft} / \mathrm{mi}^{2}$ (table 1 ). With the exception of the central Sevier basin, nearly all water used for irrigation in these basins is supplied by pumping wells located within the irrigated areas. Therefore, the irrigated areas in Milford, Aravaipa Canyon, Willcox, and Douglas basins indicate the general location of the pumping center in each valley (figs. 5 and 6).

Water-level data vary in their period of record (POR) as well as in their temporal resolution (regularity of measurements) from one site to another. The USGS NWIS database (http://waterdata.usgs.gov/nwis/gw) was searched for groundwater-levels from wells in agricultural basins in Utah and Arizona that had at least annual water-level measurements dating back more than 50 years. In select cases, both of these requirements were relaxed somewhat to include potentially valuable records. The constraints were intended to ensure that the records capture water-level responses to climatic variation over various multi-year time scales and to include a period of time where the water levels were unaffected by ground-water pumping. Declines in ground-water levels resulting from pumping were minimal prior to the early 1950s in most areas because ground-water withdrawals were negligible prior to the introduction of high-capacity submersible turbine pumps in the mid-1940s to early 1950s (Burden and others, 2004).

The physical characteristics of an aquifer and the location of a well relative to sources of recharge and discharge influence patterns of water-level variation. Therefore, wells were categorized by their aquifer condition and hydrologic setting as proposed by Hanson, Dettinger, and Newhouse (2006). Each well is assigned an aquifer condition of confined (C) or unconfined (U) and a hydrologic setting related to its location within the basin. Hydrologic settings for the wells used in the study were grouped into mountain front recharge (MF), middle basin (MB), and pumping center (PC) (table 1).

Water-level data were processed to transform all time series into a uniform format suitable for quantitative comparison (correlation) to simple moving averages of annual precipitation. At many locations, annual pumping of irrigation wells results in local drawdown during the irrigation season. Recovered water-level measurements, made at times of the year when irrigation-related pumping is not occurring, best represent the state of the aquifer with respect to climaterelated or long-term pumping-induced changes. Often, the best available measurements are those made at the end of winter and prior to the annual onset of pumping from irrigation wells.

The majority of ground-water withdrawals for irrigation in these basins generally occurs between May $1^{\text {st }}$ and September $30^{\text {th }}$. Therefore, the first step in preprocessing the selected water-level records was to remove any measurements made during the irrigation season for each year. The removal of measurements may not always be necessary for basins with minimal ground-water withdrawals. However, in order to treat all data equally, this step was performed on water levels from all wells. Water-level data were then transformed into regular time-series of annual values by using a cubic-spline interpolation to fill in small data gaps (typically 1 to 3 years) and obtain a series of regular annual water-level residuals for all records. Cubic-spline interpolation is a form of interpolation where the interpolant is a special type of function defined by piecewise polynomials.

Natural recharge rates are generally low in the arid southwestern United States, and pumping in many basins is responsible for a trend of declining water levels over the past 60 years. Conversely, in areas unaffected by pumping, unconsumed water from inefficient irrigation may enhance recharge and result in a trend of increasing water levels. In order to evaluate water-level variation caused only by changes in precipitation, the trends resulting from pumping or irrigation must be identified and removed. Water levels were examined for long-term trends by using the Mann-Kendall trend test (Helsel and Hirsch, 1992). A Mann-Kendall test is commonly used to detect time-series trends in environmental sciences (Hipel and McLeod, 2005; Prinos and others, 2002; Fenelon and Moreo, 2002). The Mann-Kendall test statistic for a time series $\left\{Z_{k}, k\right.$ $=1,2, \ldots, \mathrm{n}\}$ of data is defined as:

$$
\mathrm{T}=\sum_{j<i} \operatorname{sgn}\left(Z_{i}-Z_{j}\right)
$$

where

$$
\operatorname{sgn}(x)=\left\{\begin{array}{cc}
1, f & x>0 \\
0, f & x=0 \\
-1, f & x<0
\end{array}\right.
$$

The value reported (Mann-Kendall test statistic, T) is normalized by the standard deviation of the water-level series tested and the sign of $\mathrm{T}$ indicates the direction of the trend (positive $\mathrm{T}$ indicates increasing depth to water and thus a trend of decreasing water levels). Trends are statistically significant at the 1-percent level if the p-value is less than 0.005 (twosided statistical test). Trends of either increasing or decreasing water levels that were determined to be statistically significant were assumed to be caused by pumping or irrigation. It is possible, however, that the trends detected by the Mann-Kendall test are actually part of larger natural cycles than those examined in this study. 
In order to compare water-level records that have been influenced to varying degrees by pumping or irrigation, each record with a statistically significant trend was detrended. Detrending was accomplished by subtracting a low-order, regression-fitted polynomial from the spline-interpolated water-level series to obtain a series of water-level residuals. Trend-adjusting water-level time-series data by this method has been used to successfully eliminate anthropogenic effects such as changes in pumping or irrigation over time (Prinos and others, 2002; Hanson, Newhouse, and Dettinger, 2004). Residuals were obtained for water-level records from wells where no trend was detected (CS3, CS4, CS6, and M7, table 2) by subtracting the average water level from the entire POR. This was done so that annual water-level residuals from records that required detrending, as well as those that did not, indicate the variation about a central value (the mean or trend), making them more directly comparable for the following discussion.

No climate or drought index exists that directly reflects changes in ground-water levels or storage. Water-level residuals were compared to a selection of time-series indicators of local or regional climate to determine which of these indicators best reflected changes in ground-water levels over time. Water-level residuals were compared to annual precipitation, cumulative departures of annual precipitation, the Standard Precipitation Index (SPI) calculated for various time scales (Guttman, 1998), the Palmer Hydrologic Drought Index (PHDI) (Guttman, 1991; Guttman, 1998), and simple moving averages of annual precipitation. Comparisons were assessed

Table 2. Results of Mann-Kendall trend test on water-level records for wells in central Sevier and Milford basins in Utah and Aravaipa Canyon, Douglas, and Willcox basins in southeastern Arizona.

$[-$, no significant trend; >, greater than; <, less than $]$

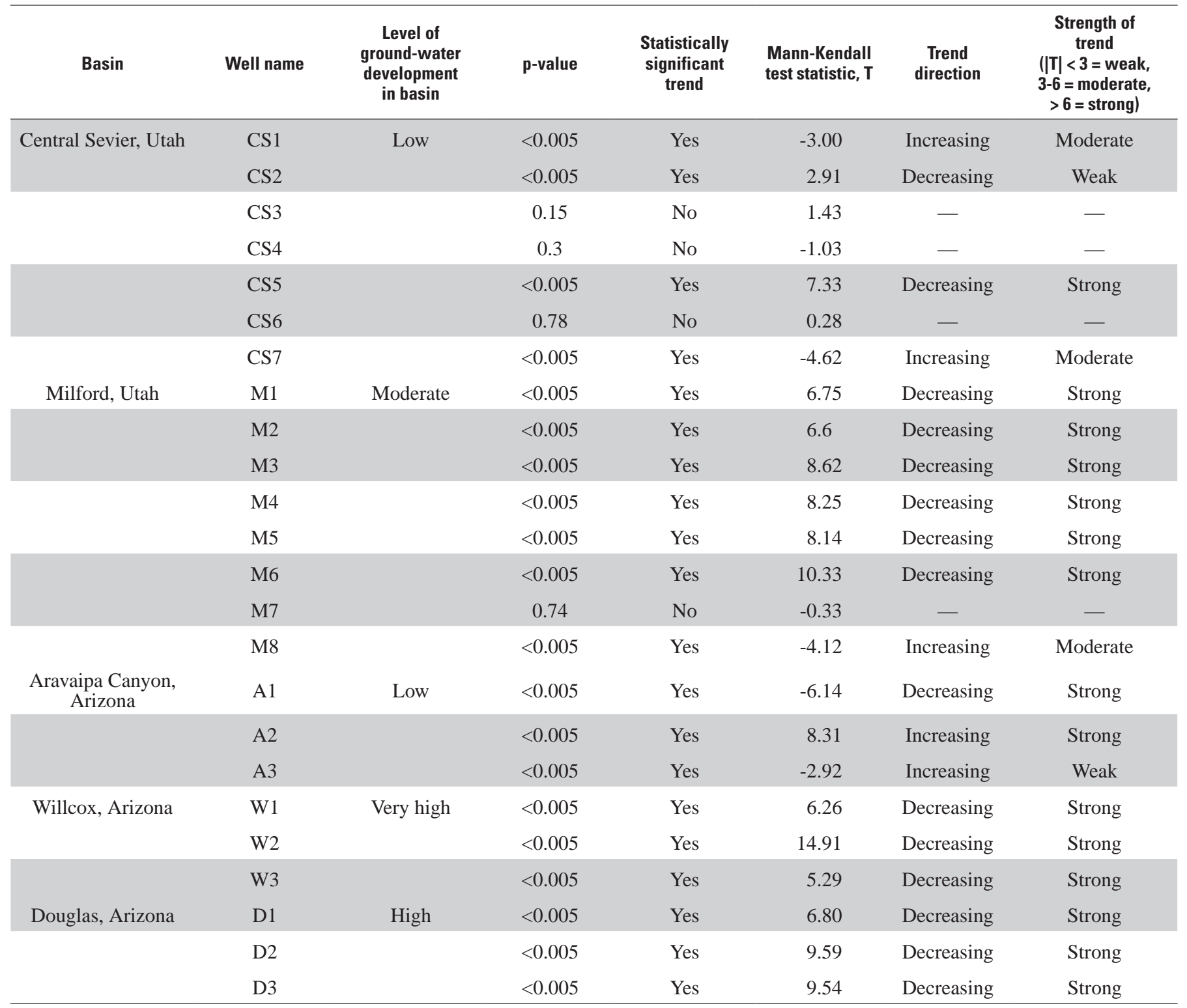


by calculating correlation coefficients between each of the indicators and each water-level residual time series. The exercise was conducted to choose a drought index or indicator of local or regional climate that is easily calculated or readily available and already widely used as a drought assessment tool for water management and planning. Obvious patterns were apparent in many of the comparisons. For example, most water-level records responded similarly in time to periods of drought indicated by the SPI or PHDI. However, the best correlations were consistently seen between water-level residuals and the moving averages of annual precipitation calculated over various time scales.

Simple moving averages of precipitation were calculated by using averages of from 2 to 10 years for the precipitation record from each basin. For example, the 10-year moving average value for a particular year, $A_{i}$, is equal to the total annual precipitation for that year, $P_{i}$, divided by the average annual precipitation for the previous 10 years, $\left(P_{i-10}+P_{i-9}+\ldots\right.$ $\left.P_{i}\right) / 10$. Correlation coefficients were calculated between each of the resulting 2- to 10-year moving averages of annual precipitation and each water-level residual time series for all wells within a basin. Correlation coefficients generally declined when moving averages were calculated from more than 10 previous years of annual precipitation data. The correlation coefficient, strictly speaking, provides a measure of the strength of a linear relation between the moving average of precipitation and the water-level residual. Although the physical relation between precipitation and water level is not likely to be linear at most wells, precipitation patterns do influence ground-water levels to varying degrees and the correlation coefficients do provide a uniform metric to describe this relation. Furthermore, the number of years used to calculate the moving average of annual precipitation that is best correlated with the water-level residuals provides some indication of the time period over which water levels respond to precipitation in the various basins and settings.

\section{Water-Level Records}

Seven wells from central Sevier basin and eight wells from Milford basin were chosen for analysis. Wells were chosen that had the most complete water-level records and longest POR in an attempt to look at water-level fluctuations prior to the onset of the high levels of pumping that generally began around 1950. Five of the seven wells from central Sevier have complete water-level measurements dating back to 1936 and have a minimum of one measurement per year for at least 92 percent of the POR (table 1, fig. 7). Although all eight of the wells chosen from Milford basin have a minimum of one measurement per year for at least 95 percent of their PORs, only two wells from this basin (M4 and M6) have relatively complete records prior to 1950 . Pre-1950 water-level records are less common in the three Arizona basins (Aravaipa Canyon, Douglas, and Willcox) and many wells in each basin were observed to show similar patterns of water-level fluctuation after about 1950. As a result, three wells from each of the Arizona basins were chosen that best meet the criteria described above. The wells (A1-A3, D1-D3, and W1-W3) have PORs that begin during 1946-55 (table 1, fig. 7). Waterlevel records from the Arizona basins were less complete, with only one well from each basin having a minimum of one measurement per year for at least 90 percent of its POR. Spline interpolations were performed on all water-level time series and successfully generated a complete record for analysis consisting of representative annual water levels for most of the wells. Multiple-year data gaps that could not be bridged with the spline interpolation exist in the water levels measured in wells A3, W1, and W3 (fig. 7).

\section{Trend Detection and Record Adjustment}

Each water-level record was tested for statistically significant trends in order to determine if the record required adjustment. The Mann-Kendall test statistic, T, was calculated for the entire POR for each well and is listed along with the corresponding $\mathrm{p}$-value in table 2 . The sign and magnitude of $\mathrm{T}$ indicate the direction and strength of the trend.

Three water-level records (CS3, CS4, and CS6) from the central Sevier basin, where ground-water development is minimal, show no long-term trends; two water-level records (CS2 and CS5) show trends of decreasing water levels; and two water-level records (CS1 and CS7) show trends of increasing water levels (table 2, fig. 7). One of the wells (CS5) with a trend of decreasing water levels is a shallow, confined, middle-basin well that was once artesian (table 1, fig. 7). It is likely that either ground-water withdrawals or the diversion of surface water away from a recharge area affecting this well has caused this water-level decline. The other well with a trend of decreasing water levels (CS2) is an unconfined mountain-front well with a POR from 1936 to 1982 that exhibits only a weak trend (table 2, fig. 7). Although it is possible that the weak trend of declining water levels in CS2 is a result of ground-water withdrawals, the trend may also be an artifact of the water-level record spanning a period of time with less-than-average precipitation. Wells CS1 and CS7 are confined middle-basin wells located down gradient from most of the irrigated area in the basin (table 1, fig. 5), suggesting that the increasing trend in ground-water levels is the result of increased recharge from surplus irrigation water.

Six of the eight wells (M1, M2, M3, M4, M5, and M6) from the Milford basin showed strong, long-term trends of declining water levels; one well (M7) showed no long-term trend; and one (M8) showed a moderate trend of increasing water levels (table 2, fig. 7). All of the wells with long-term trends of decreasing water levels are located in or adjacent to the main pumping center in Milford basin (table 1, fig. 5) and are undoubtedly affected by ground-water withdrawals. 


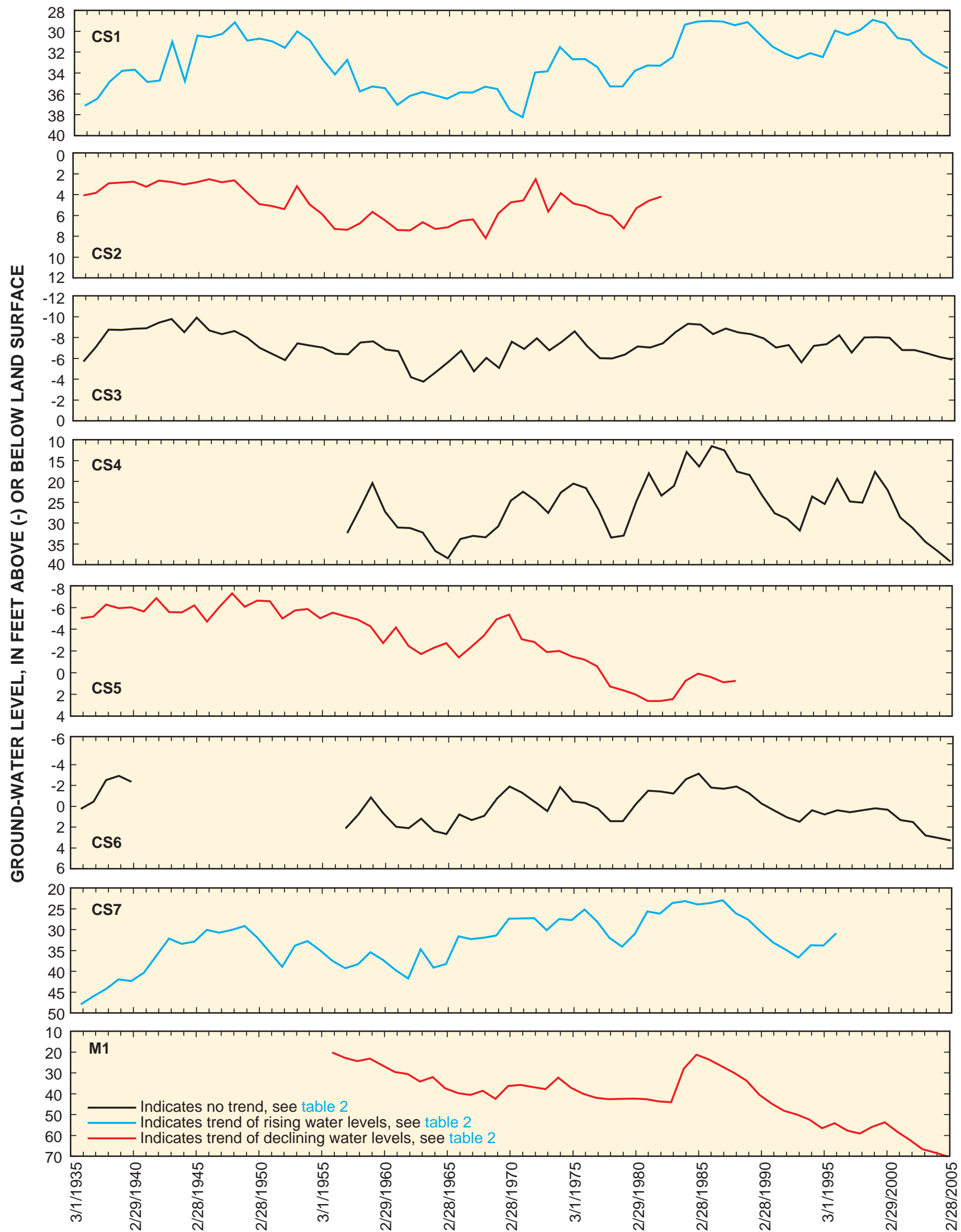

Figure 7. Spline-interpolated water-level records from central Sevier and Milford basins in Utah and Aravaipa Canyon, Douglas, and Willcox basins in southeastern Arizona, 1936-2005. 


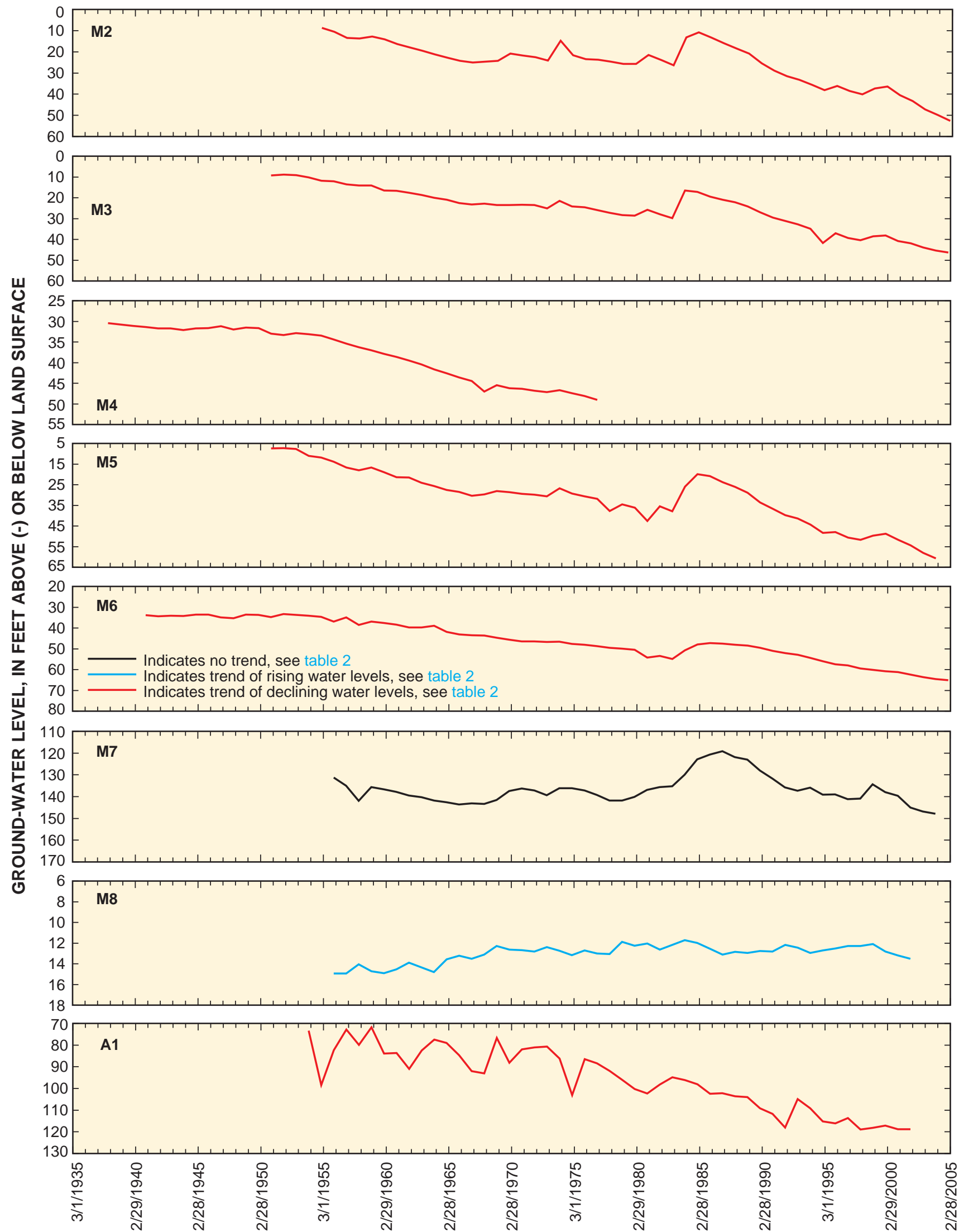

Figure 7. Spline-interpolated water-level records from central Sevier and Milford basins in Utah and Aravaipa Canyon, Douglas, and Willcox basins in southeastern Arizona, 1936-2005.-Continued 


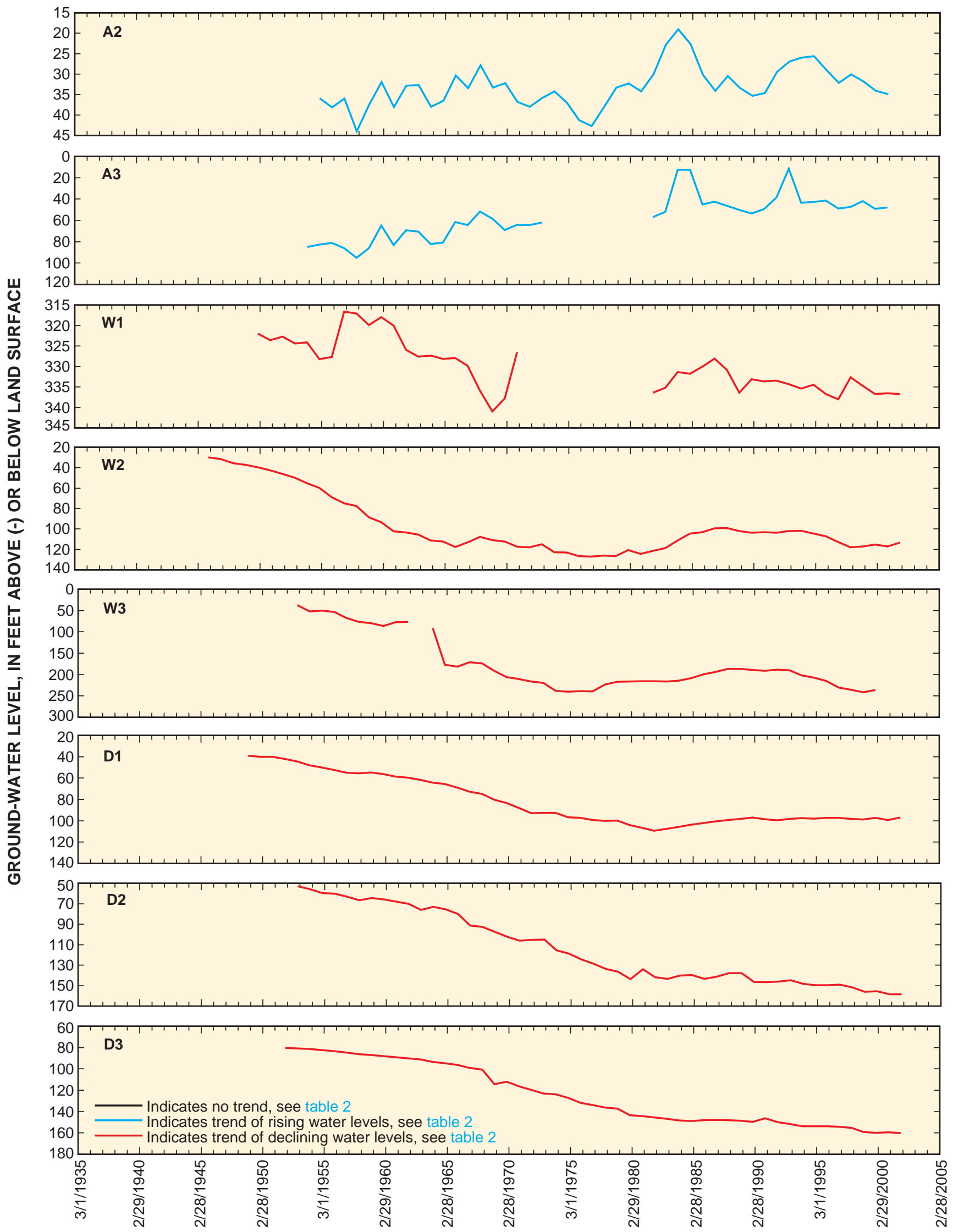

Figure 7. Spline-interpolated water-level records from central Sevier and Milford basins in Utah and Aravaipa Canyon, Douglas, and Willcox basins in southeastern Arizona, 1936-2005.-Continued 
Well M8 is located where the Beaver River delivers water to Milford basin for irrigation above an unconfined portion of the aquifer (table 1, fig. 5). The increasing water-level trend in this well is probably caused by seepage from the Beaver River recharging the aquifer.

Despite the lack of substantial ground-water development in Aravaipa Canyon basin, water-level records from this basin exhibit trends in both directions (table 2, fig. 7). Well A1, located near the border with Willcox basin showed a strong, long-term trend of declining water levels (table 2, fig. 7). Although the level of pumping is minimal in Aravaipa Canyon basin, this well is thought to be affected by the very high levels of ground-water withdrawal in the neighboring Willcox basin (table 1, fig. 4). Wells A2 and A3 are unconfined, middle-basin wells that show trends of increasing water levels. The increasing water levels in these wells may be the result of irrigation that occurs along Aravaipa Creek in the center of the valley (Arizona Department of Water Resources, 2005). It is also possible that they are the result of a multidecadal climatic trend of increasing precipitation not explicitly examined in this study. All wells from Douglas and Willcox basins in Arizona show strong trends of declining water levels and appear to be affected by high levels of pumping (tables 1 and 2, fig. 7).

\section{Water-Level Residuals and Precipitation Patterns}

Time series of water-level residuals were compared to moving averages of annual precipitation from selected precipitation stations in order to examine what effects precipitation has on the water levels and to make inferences about the physical processes that control transient changes in aquifer storage. Water-level residuals from central Sevier basin were compared to precipitation from the Richfield station (427260) in central Sevier Valley and water-level residuals from Milford basin were compared to precipitation from the Black Rock station (420730) located at the north end of Milford Valley (figs. 3 and 5). The period of record for each of these stations is 1950-2003 and 1952-2003, respectively. Precipitation records are incomplete for the stations located nearest to Aravaipa Canyon basin (Fort Grant station, 023110) and within Douglas basin (Douglas station, 022659) (fig. 4). Therefore, water-level residuals from all Arizona basins were compared to moving averages of annual precipitation from the Willcox station (029334), which recorded similar patterns of annual precipitation to the Fort Grant and Douglas stations for periods of record that each have in common (fig. 4). The period of record for the Willcox station is 1898-2004.

Moving averages of precipitation were calculated by using average annual precipitation for 2- to 10-year time periods for each precipitation station as discussed above. The water-level residual time series for each well was matched with the 2- to 10-year moving average with which it was best correlated (fig. 8). It is worth noting that the moving averages of precipitation shown in figure 8 begin at different years than the precipitation record for a particular precipitation station. This is because the first value for a 10-year moving average, for example, cannot be calculated earlier than 10 years after the start of the precipitation record for that particular station. Water-level residuals and moving averages of precipitation are negatively correlated because elevated precipitation causes water levels to rise and this is indicated by negative water-level residuals. For the purposes of this discussion, the strength of correlations between the water-level residual time series and moving averages were classified by their correlation coefficient as follows: -1 to $-0.5=$ good, -0.49 to $-0.3=$ fair, -0.29 to $-0.1=$ poor, and -0.1 to $0=$ no significant correlation (table 3 ).

Water-level residuals from all wells in the central Sevier basin show good correlations ( -0.72 to -0.51$)$ to moving averages of annual precipitation from the Richfield station (fig. 8 , table 3). Water-level residuals from five of the seven wells from the central Sevier basin (CS2, CS3, CS4, CS6, and CS7) were best correlated with 8-year moving averages of annual precipitation; and residuals from two wells, CS1 and CS5, were best correlated with 9- and 10-year moving averages of annual precipitation, respectively. Six of the seven wells from central Sevier basin (CS1, CS3, CS4, CS5, CS6, and CS7) are located along the central axis of the valley and are categorized as C-MB. One well (CS2) is located along the boundary of the alluvial deposits and categorized as U-MF (fig. 5, table 3 ). Ground-water levels in the central Sevier basin are less affected by anthropogenic stresses than ground-water levels in any of the other study basins as indicated by the results of the Mann-Kendall trend tests (table 2). The good correlations between water-level residuals from all wells in this basin and moving averages of annual precipitation indicate that precipitation-driven variations in ground-water levels can clearly be seen in areas that are not overly influenced by anthropogenic stresses. The fact that all of the water-level residual timeseries, including six from C-MB wells and one from a U-MF well, were best correlated with 8- to 10-year moving averages of annual precipitation suggests that the entire ground-water system in the central Sevier basin responds similarly in time to local precipitation.

Water-level residuals from three wells in the Milford basin show good correlation $(-0.50,-0.51$, and -0.65 for $\mathrm{M} 1$, M5, and M7 respectively) to moving averages of annual precipitation from the Black Rock station (fig. 8, table 3). Waterlevel residuals from four wells show fair correlations $(-0.37$, $-0.45,-0.43$, and -0.32 for M2, M3, M6, and M8, respectively) and water-level residuals from one well (M4) showed no significant correlation to moving averages of annual precipitation from the Black Rock station. Water-level residuals from six wells in the Milford basin are best correlated with 7- to 10-year moving averages of annual precipitation as follows: M2 and M3 residuals are best correlated with 7-year moving averages, M1 and M5 residuals are best correlated with 8-year moving averages, and M6 and M7 residuals are best correlated with 10-year moving averages. Water-level residuals from 


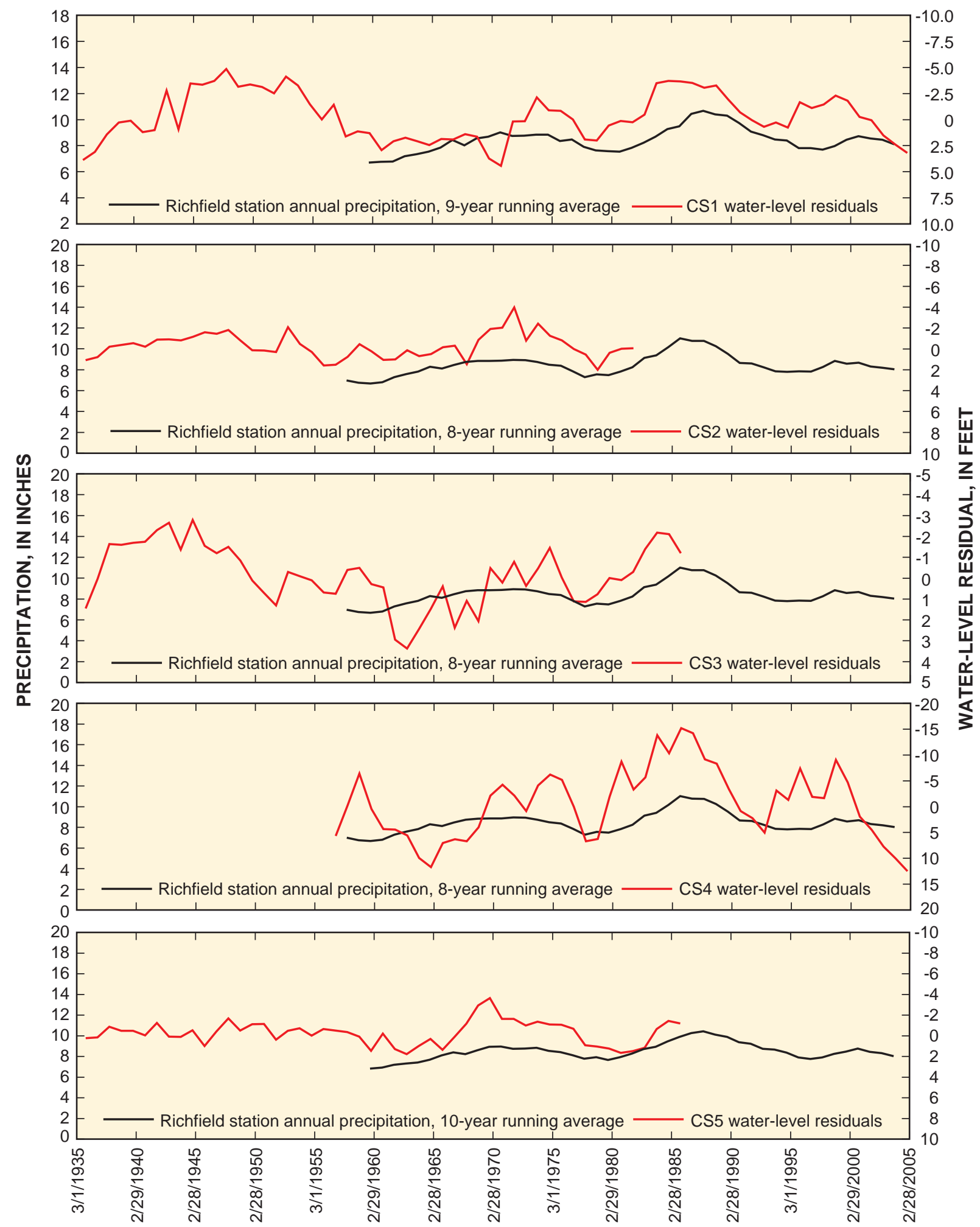

Figure 8. Water-level residuals for wells and moving averages of annual precipitation from weather stations in the central Sevier and Milford basins in Utah and Aravaipa Canyon, Douglas, and Willcox basins in southeastern Arizona, 1936-2005. 


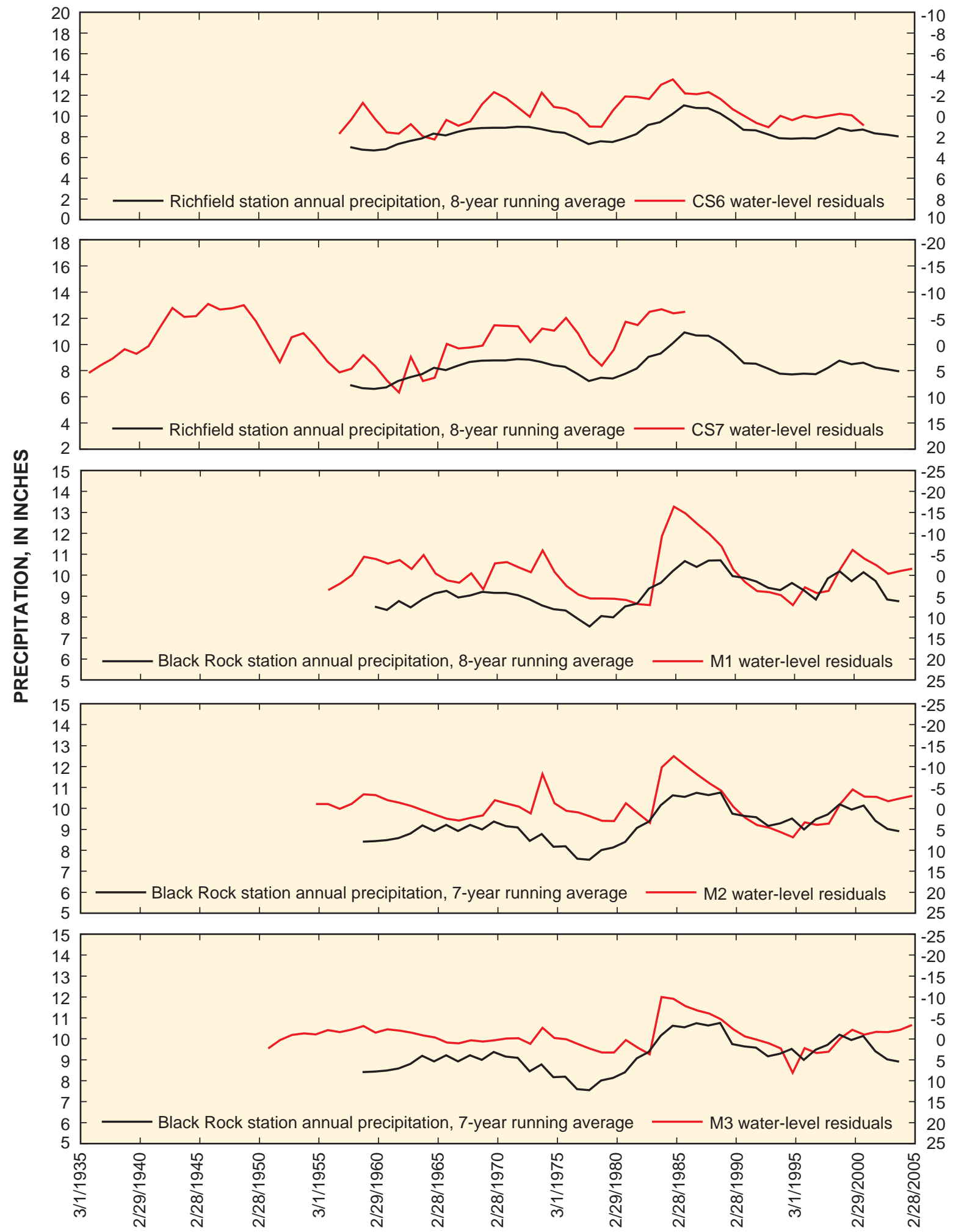

Figure 8. Water-level residuals for wells and moving averages of annual precipitation from weather stations in the central Sevier and Milford basins in Utah and Aravaipa Canyon, Douglas, and Willcox basins in southeastern Arizona, 1936-2005.-Continued 

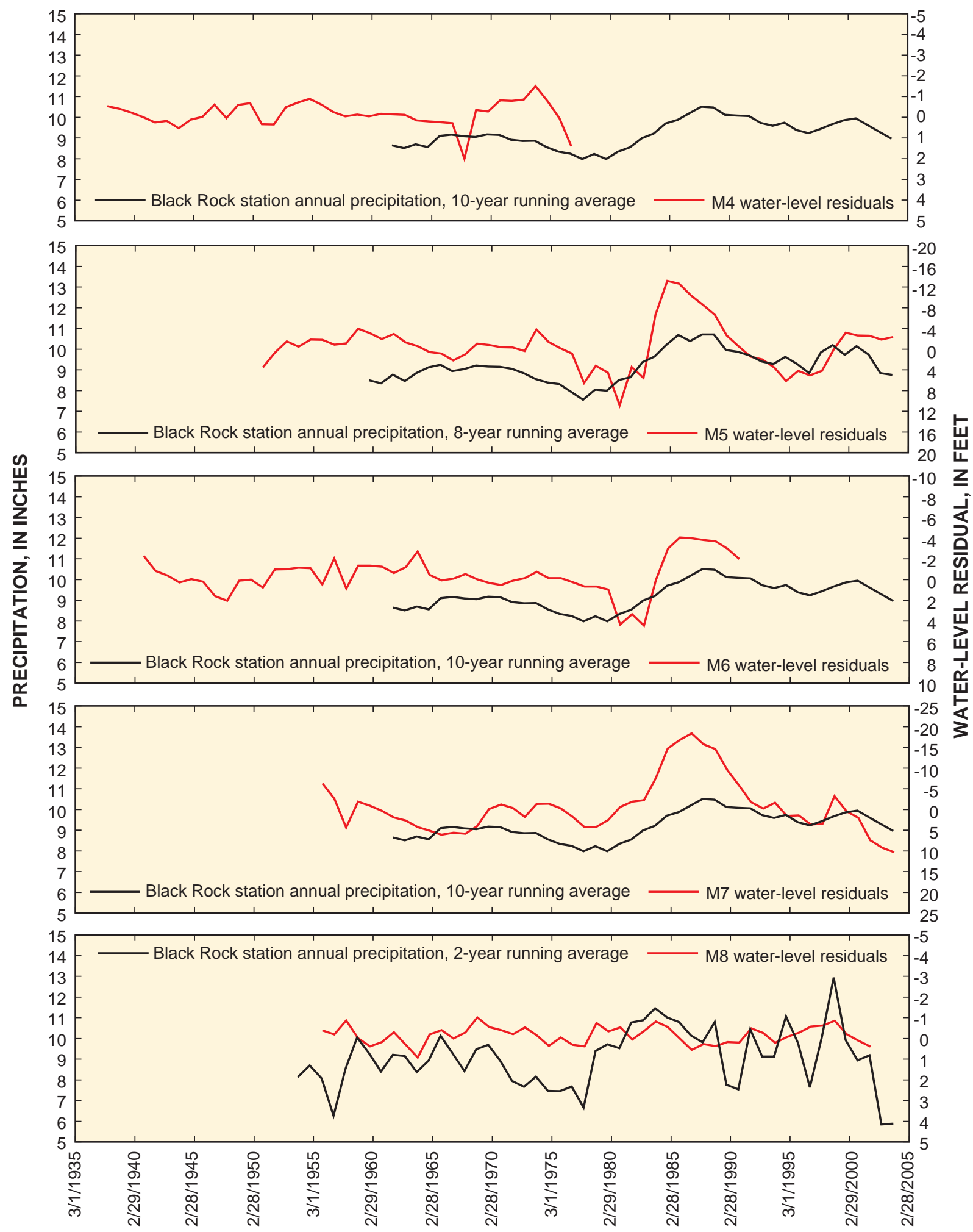

Figure 8. Water-level residuals for wells and moving averages of annual precipitation from weather stations in the central Sevier and Milford basins in Utah and Aravaipa Canyon, Douglas, and Willcox basins in southeastern Arizona, 1936-2005.-Continued 

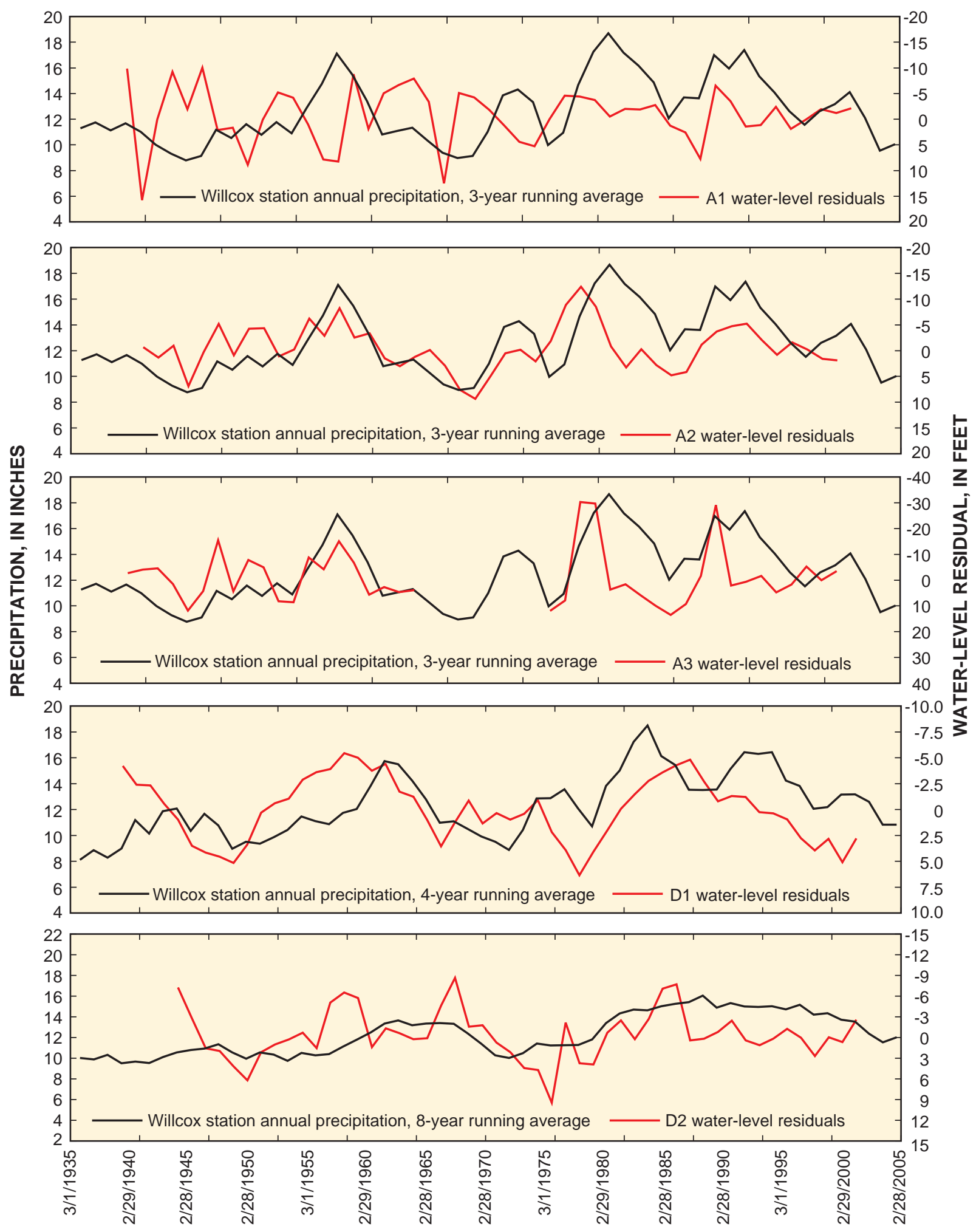

Figure 8. Water-level residuals for wells and moving averages of annual precipitation from weather stations in the central Sevier and Milford basins in Utah and Aravaipa Canyon, Douglas, and Willcox basins in southeastern Arizona, 1936-2005.-Continued 


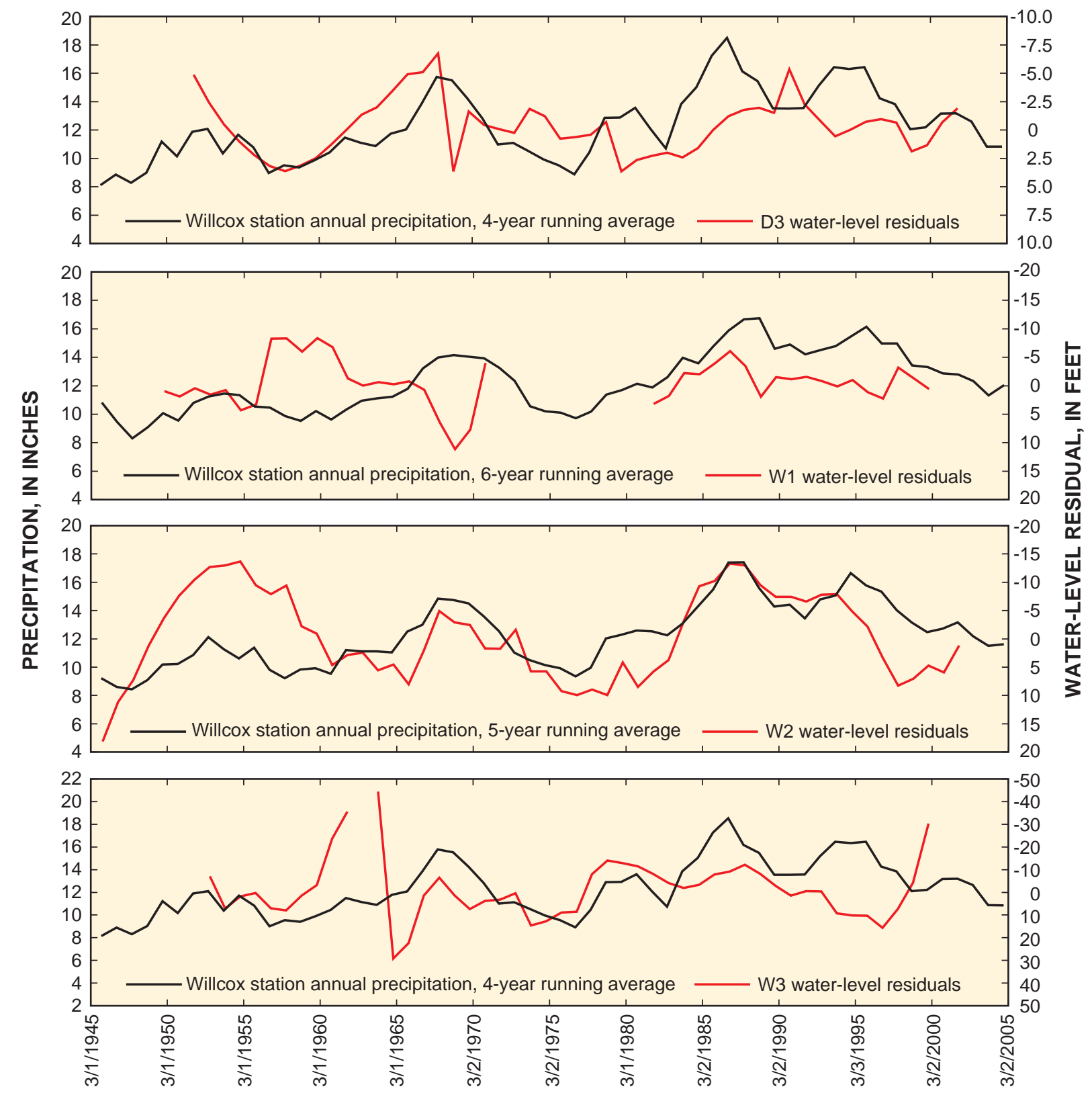

Figure 8. Water-level residuals for wells and moving averages of annual precipitation from weather stations in the central Sevier and Milford basins in Utah and Aravaipa Canyon, Douglas, and Willcox basins in southeastern Arizona, 1936-2005.—Continued

well M8 are best correlated with a 2-year moving average of annual precipitation. Of the eight wells in Milford basin, five are located near the pumping center in the middle of the valley and are categorized as C-PC (M1, M2, M3, and M5) or U-PC (M4) depending on their depth; two (M6 and M7) are located away from the main pumping center and confining layers in the center of the valley and are categorized as U-MB; and one (M8) is located near the alluvial boundary where the Beaver River enters the valley and is categorized U-MF (fig. 5, table 3). Mann-Kendall trend tests indicate that ground-water levels in the Milford basin are affected significantly more by anthropogenic stresses than ground-water levels in the central Sevier basin. This is mostly a result of higher levels of pumping that cause strong trends of declining water levels in many waterlevel records (table 2, figs. 3 and 7). Fewer good correlations exist between water-level residuals and moving averages of annual precipitation suggesting that, even after detrending, precipitation-driven variations in ground-water levels become more difficult to see as ground-water levels become increasingly influenced by anthropogenic stresses. Six out of seven of the water-level residual time series that show fair to good correlations were best correlated with 7- to 10-year moving averages of annual precipitation, similar to nearby central Sevier basin. Water-level residuals were best correlated with a 2-year moving average of annual precipitation at well CS8, suggesting that the ground-water system in this area responds 
Table 3. Correlation coefficients between water-level residual time series and moving averages of precipitation, number of years used to calculate moving average, and aquifer condition and hydrologic setting for wells in central Sevier and Milford basins in Utah and Aravaipa Canyon, Douglas, and Willcox basins in southeastern Arizona.

[Aquifer condition - hydrologic setting: $\mathrm{C}$ - confined, $\mathrm{U}$ - unconfined, $\mathrm{MB}$ - middle basin, $\mathrm{MF}$ - mountain front, $\mathrm{PC}$ - pumping center; for example, $\mathrm{C}$ - $\mathrm{MB}$ is confined - middle basin. Number of years in best correlated moving average, correlation coefficient; for example, " 9 , -0.63 " indicates a 9 -year moving average and a correlation coefficient of -0.63 ]

\begin{tabular}{|c|c|c|c|c|c|c|c|c|}
\hline & Well 1 & Well 2 & Well 3 & Well 4 & Well 5 & Well6 & Well 7 & Well 8 \\
\hline $\begin{array}{c}\text { Central Sevier basin, } \\
\text { UT }\end{array}$ & $\begin{array}{l}\mathrm{C}-\mathrm{MB} \\
9,-0.63\end{array}$ & $\begin{array}{l}\text { U-MF } \\
8,-0.53\end{array}$ & $\begin{array}{l}\text { C-MB } \\
8,-0.51 \\
\end{array}$ & $\begin{array}{l}\text { C-MB } \\
8,-0.57\end{array}$ & $\begin{array}{c}\mathrm{C}-\mathrm{MB} \\
10,-0.51\end{array}$ & $\begin{array}{l}\text { C-MB } \\
8,-0.67\end{array}$ & $\begin{array}{l}\text { C-MB } \\
8,-0.72\end{array}$ & \\
\hline $\begin{array}{c}\text { Aravaipa Canyon } \\
\text { basin, AZ }\end{array}$ & $\begin{array}{c}\text { U-MB } \\
3,-0.03\end{array}$ & $\begin{array}{l}\text { U-MB } \\
3,-0.49\end{array}$ & $\begin{array}{l}\text { U-MB } \\
3,-0.41 \\
\end{array}$ & & & & & \\
\hline Douglas basin, AZ & $\begin{array}{c}\text { U-PC } \\
4,-0.33\end{array}$ & $\begin{array}{c}\text { U-PC } \\
8,-0.25\end{array}$ & $\begin{array}{c}\text { U-PC } \\
4,-0.24\end{array}$ & & & & & \\
\hline
\end{tabular}

\begin{tabular}{|c|}
\hline Strength of correlation \\
\hline-1 to $-0.5=$ good correlation \\
\hline-0.49 to $-0.3=$ fair correlation \\
\hline-0.29 to $-0.1=$ poor correlation \\
\hline-0.1 to $0=$ no significant correlation \\
\hline
\end{tabular}

to shorter-term precipitation patterns. Well CS8 is an unconfined, mountain-front well that may be more directly connected to recharge occurring on the valley floor or originating as seepage from the Beaver River channel.

In Aravaipa Canyon basin, water-level residuals from two wells (A2 and A3) showed fair correlations (-0.49 and -0.41 , respectively) to 3 -year moving averages of annual precipitation from the Willcox station and residuals from one well (A1) showed no significant correlation (fig. 8, table 3 ). The fact that the best correlations are seen between water-level residuals and 3-year moving averages of annual precipitation in this basin implies that the ground-water system responds more quickly to local precipitation patterns than was seen in the Utah basins. All three Aravaipa Canyon basin wells (A1, A2, and A3) are located along the center of a valley with very little pumping and were categorized as U-MB (fig. 6, table 3). The best correlation is seen in well A2 which tested negative for any long-term trends (table 2). It is noteworthy that well A1 is located near the boundary between Aravaipa Canyon and Willcox basins and the high level of pumping in Willcox basin is likely the cause of the long-term water-level decline seen in that well (table 2, fig. 7).

Willcox and Douglas basins are more similar in their size, climate, and level of ground-water development than any of the other basins considered in this study. Water-level residuals from one well in Willcox basin (W2) showed fair correlation $(-0.41)$ with a 5-year moving average of annual precipitation from the Willcox station and residuals from another well (W1) were poorly correlated (-0.19) with a 6-year moving average of annual precipitation (fig. 8, table 3). Water-level residuals from well W3 displayed no significant correlation to moving averages of precipitation. Well W1 is a shallow well located on an alluvial fan coming off of the Dos Cabezas Mountains and was categorized as U-MF. Wells W2 and W3, categorized C-PC, are both relatively deep $(1,356 \mathrm{ft}$ and 381 $\mathrm{ft}$, respectively) and located within pumping centers along the central axis of Willcox Valley. Water-level residuals from one well in Douglas basin (D1) showed a fair correlation (-0.33) to a 4-year moving average of annual precipitation from the Willcox station and residuals from two other wells, (D2 and D3) showed only poor correlation to 8- and 4-year moving averages of annual precipitations, respectively (fig. 8, table 3). All three wells in Douglas basin are located along the central axis of the valley and are categorized as U-PC.

Willcox and Douglas basins have experienced substantially higher rates of pumping than any of the other basins considered in this study and water-level records from all of the wells from both of these basins exhibited strong trends of decreasing water levels (table 2, fig. 7). Thus, the lack of any good correlation between water-level residuals and moving averages of precipitation (and only fair correlation at two of six wells) reinforces the idea that precipitation-driven variations in ground-water levels become more difficult to see as ground-water levels become increasingly influenced by anthropogenic stresses. The best correlations are seen between water-level residuals for W2 and D1 and moving averages of annual precipitation from the Willcox station. It is worth noting that these two wells have the most complete water-level record of all wells examined in both of these basins (table 1). 


\section{Evaluation of the Effects of Precipitation}

The initial intent of the study was to develop a method, or to utilize existing methods, to separate the fraction of waterlevel variation caused by climate from the fraction of waterlevel variation caused by anthropogenic stresses that would have broad application by using existing records of groundwater levels and a familiar climate index. During the course of the study, data constraints were encountered and the study objectives had to be modified. Familiar climate indices (such as Palmer Drought indices) are not designed to account for variations in ground-water storage and are not generally wellcorrelated with water-level variation. Most existing records of ground-water levels are not sufficient in their length, completeness, or temporal resolution to successfully apply quantitative frequency analysis methods (such as Chen and others, 2002; Hanson, Newhouse, and Dettinger, 2004). Finally, any method used to remove long-term trends from a water-level time series is imperfect. The non-linear relation between ground-water levels and the physical factors that control them make it impossible to know if detrending removed only the fraction of water-level variation imparted by anthropogenic stresses, if it removed all of that variation, or if it also removed parts of natural, climate-driven cycles. Despite these problems, precipitation-driven patterns in annual water-level variations do exist that permit meaningful interpretation of existing data.

In a completely undeveloped southwestern basin, most variation in ground-water levels should be directly driven by precipitation that becomes recharge of one form or another. Records of ground-water levels were processed with the intent of minimizing the water-level variation resulting from anthropogenic stresses, thereby enhancing patterns that arise from these precipitation-driven stresses. Water-level responses to precipitation patterns might be delayed to varying degrees by factors such as the location and mechanisms of recharge or the storage capacity of the aquifer. For example, water levels in wells near a stream channel might respond rapidly in response to focused infiltration through the streambed. Conversely, middle-basin wells might respond slowly to recharge that originates as diffuse infiltration of snowmelt over a neighboring mountain block where the time it takes for infiltration to reach the water table is long and the storage capacity of the mountain block is large.

Water-level residuals from wells where correlations in table 3 are fair or good were examined with the goal of making inferences about the physical factors that control precipitation-driven variations in ground-water levels. These wells include CS1, CS2, CS3, CS4, CS5, CS6, and CS7 from central Sevier basin; M1, M2, M3, M5, M6, M7, and M8 from Milford basin; A2 and A3 from Aravaipa Canyon basin; W2 from Willcox basin; and D1 from Douglas basin (table 3). Most water-level residuals from wells in the Utah basins are best correlated with 7- to 10-year moving averages of annual precipitation while all of the water-level residuals (with fair to good correlations) from the Arizona basins are best correlated with 3- to 5-year moving averages of annual precipitation. The Utah basins appear to respond more slowly to precipitation patterns than the Arizona basins. This difference may be related to the dominant recharge mechanisms in the basins. The Utah basins receive more high-altitude precipitation from winter storms, resulting in diffuse infiltration of snowmelt in the mountains. This process involves slow percolation through deep unsaturated zones. Furthermore, the water-level response to this recharge in valley wells is buffered by the large storage capacity of the mountain block. A larger fraction of the annual precipitation in the Arizona basins is supplied by the summer monsoons. Hanson, Dettinger, and Newhouse (2006) determined that a substantial percentage of the variation in ground-water level time series from southern Arizona basins was correlated with monsoonal-like periods. Mountain-front recharge and streambed infiltration of runoff are the major sources of recharge to all of the Arizona basins. These types of recharge, more focused and episodic, occur closer to the valley water table and likely result in ground-water level responses that are less buffered by aquifer storage and that occur over shorter periods of time.

Residuals from well M8 in the Milford basin are best correlated with only a 2-year moving average of annual precipitation. This shallow, mountain-front (U-MF) well is in an unconfined part of the alluvial aquifer (tables 1 and 3, fig. 5) located near the Beaver River. It is the only one of the Milford wells exhibiting a trend of increasing water levels (table 2, fig. 7) suggesting that it is in an area recharged by seepage of surface water delivered for irrigation through the Beaver River. Water-level residuals from this well are best correlated with a moving average of annual precipitation calculated over a much shorter period of time than other wells in this basin (all 7- to 10-year moving averages), suggesting that water levels in this area are responding to streambed infiltration. Despite the indirect relation between ground-water levels and multi-year moving averages of precipitation, this relation provides useful information based on existing data.

The results of this study do not yield quantitative estimates of the amount of water-level rise or decline that is associated with particular precipitation events or patterns. However, visual inspection of figure 8 illustrates that waterlevel residuals generally mimic moving averages of annual precipitation, which are essentially smoothed and timedelayed versions of the original time series of annual precipitation. Selected peaks in precipitation records from the Utah and Arizona basins are discussed as examples. In the Utah basins, three multi-year periods with generally average to greater-than-average precipitation are: 1961-69, 1980-88, and 1994-2000 (fig. 3). In the Arizona basins, more year-to-year variation is seen in the annual precipitation records. Example periods of greater-than-average precipitation in the Arizona basins are: 1961-67, 1977-78, 1980-88, and 1990-94 (fig. 4). Peaks that reflect these high-precipitation years are seen in all water-level residual time series with fair to good correlations (CS1, CS2, CS3, CS4, CS5, CS6, CS7, M1, M2, M3, M5, M6, 
M7, and M8 in the Utah basins; and A2, A3, W2, and D1 from the Arizona basins). Methods do exist that have had some success quantitatively relating variation in ground-water levels to particular climatic events (Hanson, Dettinger, and Newhouse, 2006) or predicting the amount of expected water-level change based on precipitation records (Chen and others, 2002). However, these methods rely on water-level data of substantially higher temporal resolution to perform successful frequency analysis or to determine coefficients used in empirical models.

Wells with water-level residuals that showed no correlation or poor correlation to moving averages of annual precipitation include M4 from Milford basin; A1 from Aravaipa Canyon basin; W1 and W3 from Willcox basin; and D2 and D3 from Douglas basin (table 3). It is not possible to resolve precipitation-driven variation in ground-water levels from these wells. Two factors appear to be responsible for the lack of correlation to moving averages of annual precipitation in these wells: a high level of ground-water development and a short or incomplete water-level record. The best correlations were seen in the Utah basins where ground-water development exists at low to moderate levels (less than 0.15 acre-ft/ $\mathrm{mi}^{2}$ ) and water-level records for 14 out of 15 wells had annual measurements for at least 92 percent of their POR (tables 1 and 3, figs. 3 and 8). In the Arizona basins, no good correlations were determined at all and water-level residuals from only one well in Willcox basin and one well in Douglas basin were determined to have fair correlation to moving averages of precipitation. Historically, Willcox and Douglas basins have experienced substantially higher levels of ground-water development than any of the other study basins and the wells with the best correlations are generally those with the longest and most complete water-level records (tables 1 and 3, figs. 4 and 8). Well A1, showing no significant correlation, is an exception in that it is located within the minimally developed Aravaipa Canyon basin and has a 90-percent complete POR (table 1). However, water-levels from this well exhibit a strong declining trend (table 2, fig. 7) and appear to be affected by pumping in the neighboring, highly developed, Willcox basin. The one well from Milford basin that showed no correlation (M4) has a POR that is coincident with the corresponding precipitation record for only 17 years (1961-77) (fig. 8). Although these conclusions are based on data from few wells, and although there may be other factors contributing to poor correlations, it seems clear that high levels of pumping can obscure precipitation-driven water-level variation and that short or incomplete water-level records are insufficient for examining these patterns.

\section{Summary and Conclusions}

Increased withdrawals from alluvial aquifers of the southwestern United States during the last half century have magnified the effects of drought on ground-water levels in valleys where withdrawals for irrigation are greatest. Further- more, during wet periods, reduced withdrawals have exaggerated the response to natural recharge observed in ground-water levels. In order to manage water resources more effectively, analysis of ground-water levels under the influence of natural and anthropogenic stresses is useful.

This report evaluates the effects of local precipitation patterns on water-level records from wells in various hydrogeologic settings in five basins in Utah and Arizona. Precipitation-driven variation is evident in existing records of annual ground-water levels, including those that have been influenced to varying degrees by anthropogenic stresses. These records can be used to make general inferences about the physical parameters controlling ground-water systems within a basin and across various hydrologic settings. These records can also be used to examine the time span over which parts of an aquifer are affected by precipitation patterns. The methods described in this report could be used to investigate how many years of drought of a particular magnitude, for instance, are required before ground-water levels in a basin are substantially impacted with and without the influence of ground-water pumping.

Hydrologic data were examined from two basins in Utah (Milford and central Sevier) and three in Arizona (Aravaipa Canyon, Douglas, and Willcox). Records of ground-water levels and basin-wide total annual ground-water withdrawals were examined along with simple moving averages of annual precipitation from valley precipitation stations. Water-level records were transformed into regular time series of annual water-level measurements by first removing pumping-season measurements and then performing spline interpolations. Mann-Kendall trend tests were performed and showed that most water-level records from heavily developed basins exhibit strong trends of declining water levels caused by pumping. A few water-level records from the less-developed basins showed trends of increasing water levels that are likely related to the infiltration of unconsumed irrigation water. Water-level records were detrended by subtracting a regression-fitted low-order polynomial in an attempt to eliminate the variation that results from these anthropogenic effects. Waterlevel residuals were then correlated with 2- to 10-year moving averages of annual precipitation from representative stations from the various basins. The water-level residual time series for each well was matched with the 2- to 10-year moving average of annual precipitation with which it was best correlated and the results were compared across basins and hydrologic settings.

Correlations between water-level residuals and moving averages of annual precipitation examined in this study suggest that precipitation-driven variation in ground-water levels is strongly influenced by the dominant mechanism of recharge, by the time required for infiltration to reach the water table, and by the storage capacity of the aquifer. Water-level residuals from most wells in the Utah basins were best correlated with 7- to 10-year moving averages of annual precipitation, suggesting that they respond to recharge originating as diffuse infiltration of snowmelt in the mountains. Recharge originat- 
ing over the mountains may involve slow percolation through deep unsaturated zones, and water levels in valley aquifers are buffered by the large storage capacity of the mountain block. Water-level residuals from one well in Milford basin (Utah), in an area recharged by streambed infiltration from the Beaver River, were best correlated with 2-year moving averages of annual precipitation. Water-level residuals from wells in Arizona basins, where the major source of recharge occurs along the valley margins as streambed infiltration, were best correlated with 3- to 5-year moving averages of annual precipitation. Mountain-front recharge and streambed infiltration in these basins generally occur along valley margins where aquifers are unconfined, allowing infiltration to reach the water table and causing ground-water levels to rise in less time than from mountain-block recharge.

The ability to resolve precipitation-driven water-level variation is limited by the degree to which the water levels are influenced by pumping, by incomplete water-level records, and by data of low temporal resolution. Correlations between water-level residuals and annual averages of precipitation were generally better from wells in basin that had experienced lower levels of ground-water development and from wells that had at least one water-level measurement per year over the POR. Detrended water-level records from wells that experienced substantial long-term water-level declines in heavily pumped basins were not well correlated with precipitation records.

Climate change is predicted to affect sources of recharge to southwestern aquifers as the demand for ground water increases in the southwestern United States. In order to improve the utility of water-level records for making waterresource decisions, improvements should be made in relation to the location of monitoring wells and measurement frequency. Monitoring wells located both in and away from pumping centers, but from otherwise similar hydrologic settings, would allow water-level records from wells heavily influenced by pumping to be correlated with wells similarly affected by precipitation but less influenced by pumping. Long-term monthly or quarterly water-level measurements would allow application of more-rigorous and quantitative methods. Despite the limitations of existing data, the results of this study should aid in the future examination of water-level records in other basins in the southwestern United States.

\section{Acknowledgments}

The authors would like to acknowledge the support of the Ground Water Resources Program of the U.S. Geological Survey Office of Ground Water. The authors also would like to thank Alice Konieczki of the USGS for assisting in the compilation of hydrologic information from the Arizona basins, Timothy McKinney of the USGS for assisting in the compilation of spatial data from Utah and Arizona, and Randall Hanson and John Hoffman of the USGS for providing technical reviews of this report.

\section{References Cited}

Alley, W.M., 2001, Ground water and climate: Ground Water, v. 39 , no. 2 , p. 161.

Arizona Department of Water Resources, 2005, Rural Arizona Watershed Alliance (RAWA) Section, Southeastern Arizona Planning Area, accessed August 30, 2005, at http:// www.azwater.gov/dwr/Content/Find_by_Program/Rural_ Programs/O utsideAMAs_PDF s_for_web/Southeastern_ Arizona_Planning_Area/default.pdf

Burden, C.B., and others, 2004, Ground-water conditions in Utah, Spring of 2003: Utah Division of Water Resources Cooperative Investigations Report No. 44, 128 p.

Chen, Z., Grasby, S.E., and Osadetz, K.G., 2002, Predicting average annual groundwater levels from climatic variables: an empirical model: Journal of Hydrology, v. 260, p. 102-117.

Coates, D.R., Cushman, R.L., and Hatchett, J.L., 1955, Geology and ground-water resources of the Douglas basin, Arizona, with a section on the chemical quality of the ground water: U.S. Geological Survey Water-Supply Paper 1354, $56 \mathrm{p}$.

Dettinger, M.D., and Earman, S., 2007, Western ground water and climate change-Pivotal to supply sustainability or vulnerable in its own right?: Association of Ground Water Scientists and Engineers Newsletter, June 2007, p. 4-5.

Fenelon, J.M., and Moreo, M.T., 2002, Trend analysis of ground-water levels and spring discharge in the Yucca Mountain region, Neveda and California, 1960-2000: U.S. Geological Survey Water-Resources Investigations Report 02-4178, 97 p.

Fenneman, N.M., 1931, Physiography of western United States: New York, McGraw-Hill, 534 p.

Guttman, N.B., 1991, A sensitivity analysis of the Palmer Hydrologic Drought Index: Water Resources Bulletin, v. 27, p. 797-807.

Guttman, N.B., 1998, Comparing the Palmer Drought Index and the Standardized Precipitation Index: Journal of the American Water Resources Association, v. 34, p. 113-121.

Hanson, R.T., Martin, P., and Koczot, K.M., 2002, Simulation of ground-water/surface-water flow in the Santa ClaraCalleguas Basin, Ventura County, California: U.S. Geological Survey Water-Resources Investigations Report 02-4136, 214 p.

Hanson, R.T., Newhouse, M.W., and Dettinger, M.D., 2004, A methodology to assess relations between climatic variability and variation in hydrologic time series in the southwestern United States: Journal of Hydrology, v. 287, p. 252-269. 
Hanson, R.T., Dettinger, M.D., and Newhouse, M.W., 2006, Relations between climatic variability and hydrologic time series from four alluvial basins across the southwestern United States: Hydrogeology Journal, v. 14, p. 1122-1146.

Helsel, D.R., and Hirsch R.M., 1992, Statistical methods in water resources: Amsterdam, Elsevier, 510 p.

Hipel, K.W., and McLeod, A.I., 2005. Time series modelling of water resources and environmental systems: Electronic reprint of book originally published in 1994, accessed June 2005 at http://www.stats.uwo.ca/faculty/aim/1994Book/.

Konieczki, A.D., and Heilman, J.A., 2004, Water-use trends in the Desert Southwest-1950-2000: U.S. Geological Survey Scientific Investigations Report 2004-5148, 40 p.

Lambert, P.M., Mason, J.L., and Puchta, R.W., 1995, Hydrology of the Sevier-Sigurd ground-water basin and other ground-water basins, central Sevier Valley, Utah: Utah Department of Natural Resources Technical Publication No. 103, $181 \mathrm{p}$.

Mann, L.J., and English, C.S., 1980, Maps showing groundwater conditions in the Douglas basin area, Cochise County, Arizona-1978: U.S. Geological Survey Water-Resources Investigations Open-File Report 80-700, 3 sheets.

Mann, L.J., White, N.D., and Wilson, R.P., 1978, Maps showing ground-water conditions in the Willcox area, Cochise and Graham Counties, Arizona-1975: U.S. Geological Survey Water-Resources Investigations Report 78-60, 3 sheets.

Mason, J.L., 1998, Ground-water hydrology and simulated effects of development in the Milford area, an arid basin in southwestern Utah: U.S. Geological Survey Professional Paper 1409G, 69 p.

Maupin, M.A., and Barber, N.L., 2005, Estimated withdrawals from principal aquifers in the United States, 2000: U.S. Geological Circular 1279, 47 p.

Merideth, R., 2000, A primer on climate variability and change in the southwest: Tucson, Ariz., University of Arizona, Udall Center for Studies in Public Policy and the Institute for the Study of Planet Earth, 28 p.

Mower, R.W., and Cordova, R.M., 1974, Water resources of the Milford area, Utah, with emphasis on ground water: Utah Department of Natural Resources Technical Publication No. 43, 106 p.

Neuman, S.P., and Adar, U., 1983, Estimation of recharge in a small southern Arizona basin by means of hydrological, hydrochemical, and environmental isotope data: University of Arizona, Tucson, a report for the Office of Water Research and Technology, U.S. Department of Interior, Project Number A-099-Ariz, 134 p.
Planert, Michael, and Williams, J.S., 1995, Ground-water atlas of the United States-Segment 1, California, Nevada: U.S. Geological Survey Hydrologic Investigations Atlas 730-B, $28 \mathrm{p}$.

Prinos, S.T., Leitz, A.C., and Irvin, R.B., 2002, Design of a real-time ground-water level monitoring network and portrayal of hydrologic data in southern Florida: U.S. Geological Survey Water-Resources Investigations Report 01-4275, $108 \mathrm{p}$.

Seager, R., Ting, M.F., Held, I.M., Kushnir, Y., Lu, J., Vecchi, G., Huang, H.P., Harnik, N., Leetmaa, A., Lau, N.C., Li, C., Velez, J., and Naik, N., 2007, Model projections of an imminent transition to a more arid climate in southwestern North America: Science, v. 316, no. 5828, p. 1181-1184.

Spatial Climate Analysis Service, 2004, Parameter-elevation Regressions on Independent Slopes Model (PRISM): Oregon State University data, accessed April 2005 at http:// www.prism.oregonstate.edu/.

Sufflita, M., and Kern, J.W., 2001, Correlation between natural spring flow and the Palmer Hydrologic Drought Index, in National Meeting of the American Society for Surface Mining and Reclamation, June 3-7, 2001, Proceedings: Albuquerque, N. Mex., American Society for Surface Mining and Reclamation, $11 \mathrm{p}$.

Tadayon, Saeid, 2005, Water withdrawals for irrigation, municipal, mining, thermoelectric-power, and drainage uses in Arizona outside of active management areas, 1991-2000: U.S. Geological Survey Scientific Investigations Report 2004-5293, 28 p.

United Stated Department of Agriculture-National Resources Conservation Service, 1999, 12-Digit Watershed Boundary Data, scale 1:24,000, accessed April 2005 at http://datagateway.nrcs.usda.gov/G atewayH ome.html.

U.S. Geological Survey, 1991, National water summary, 1988-89: U.S. Geological Survey Water-Supply Paper 2375, $591 \mathrm{p}$.

U.S. Geological Survey, 2008, USGS groundwater information, Collection of basic records (CBR) program, accessed February 22, 2008, at http://water.usgs.gov/ogw/CBR.html .

Venencio, M.V., 2002, Climate variability and ground water resources, in Sixth International Conference on Southern Hemisphere Meteorology and Oceanography, February 2002, Proceedings: Long Beach, Calif., American Meteorological Society, p. 142-144.

Western Regional Climate Center, 2005, Western U.S. Climate Historical Summaries, accessed May 2005, at http:// www.wrcc.dri.edu/Climsum.html. 



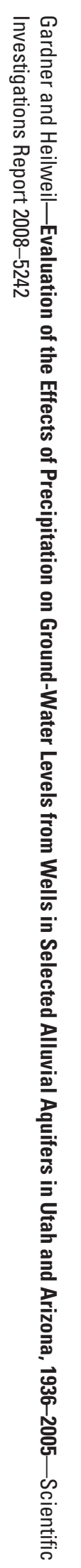

